\title{
DE CORTES Y FIESTAS CORTESANAS EN LA AMÉRICA HISPANA: UNA APROXIMACIÓN BIBLIOGRÁFICA ${ }^{1}$
}

\author{
Patricio Hidalgo Nuchera \\ (Universidad Autónoma de Madrid)
}

\section{RESUMEN}

El presente trabajo ofrece una visión panorámica sobre la corte y las fiestas cortesanas en la América hispana. Si bien la producción historiográfica es escasa si la cotejamos con la existente para la metrópoli, en los últimos años -y como puede comprobarse en la bibliografía que adjuntamos como anexo- se están llevando a cabo considerables esfuerzos para cerrar esta brecha, especialmente en los territorios de los antiguos virreinatos de México y el Perú.

PALABRAS CLAVE: Cortes virreinales, fiestas cortesanas, celebraciones dinásticas, elementos de la fiesta política, tipos de fiestas políticas, celebraciones extraordinarias, fiesta del Corpus Christi, fiestas patrias, Filipinas.

\section{ABOUT COURTS AND COURTLY CELEBRATIONS IN HISPANIC AMERICA: A LITERATURE APPROACH}

\begin{abstract}
This paper provides an overview of the Court and courtly celebrations in Hispanic America. Although available historical literature on the topic is scant in relation to the mother country, there has been much effort in recent years to fill the gap (especially as regards the old viceroyalties in Mexico and Peru). The literature cited here testifies to the effort.
\end{abstract}

KEYWORDS: Viceroyal courts, courtly festivities, dynastic celebrations, elements of political celebrations, types of political celebrations, extraordinary celebrations, the Corpus Christi festivity, national festivities, the Philippines.

\footnotetext{
${ }^{1}$ Esta investigación se ha desarrollado dentro del Proyecto de Investigación Humanistas españoles. La tradición clásica y bumanistica en España y América. Narrativas no oficiales, siglos XVI-XVIII, financiado por el Ministerio de Educación y Ciencia (rf. FF2012-37448-C04-01).
} 


\section{CORTE REAL, CORTES VIRREINALES Y CORTES PROVINCIALES}

En las últimas décadas la historiografía sobre la corte y las cortes ha conocido un impulso extraordinario. Martínez Millán, que ha analizado la evolución del concepto de corte así como la estructura de la Monarquía Hispánica, ha puesto de manifiesto que las relaciones entre el rey -fuente de legitimidad y de gracia- y las distintas élites políticas de sus reinos estaban regidas por los principios de "patronazgo» y «clientelismo» ${ }^{2}$. Ello demostraría que estamos ante una estructura política moderna y descentralizada en la que «el poder del monarca no era absoluto o único sino preeminencial, por lo que debía gobernar a través de mediaciones y no de manera directa o centralista» ${ }^{3}$.

Por otra parte, los estudios sobre la Monarquía Hispánica de los Habsburgo han mostrado a ésta como paradigma de las «monarquías compuestas» europeas de la época moderna. En este sentido, Álvarez-Ossorio Alvariño ha caracterizado aquélla como una «monarquía de cortes», en la que si bien en unos casos se reforzaron «espacios cortesanos preexistentes (Nápoles, Palermo, Milán, Bruselas, Lisboa), en otros se llevó a cabo la creación de cortes virreinales de nuevo cuño (Lima, México) sobre los centros de los imperios precolombinos» ${ }^{4}$. Más tarde, C. Büschges apuntó que esta original organización tenía su razón de ser en que, dada su extensión geográfica y estructura compuesta, la corte madrileña era incapaz de defender sus intereses en los distintos reinos y de mantener la fidelidad y el apoyo de las élites políticas locales. En dicha «monarquía de cortes», los virreyes y sus respectivas cortes virreinales jugaron un valioso papel en la integración de los territorios y sus élites políticas en la monarquía común ${ }^{5}$.

Aún más y como señala un estudio reciente de Rivero Rodríguez, la imagen que se está imponiendo en la historiografía actual es la de una monarquía en la que prevalece, no la idea de dominación unilateral -al estilo de los imperios coloniales del siglo XIX-, sino la de un mundo en sí mismo, articulado por una red compleja de intercambios internos. Más que una dominación sobre el territorio, lo que había era

\footnotetext{
2 José Martínez Millán, “La corte de la monarquía hispánica”, Studia Historica. Historia Moderna 28 (2006): 17-61.

${ }^{3}$ Martínez Millán, "Introducción. La investigación sobre las élites de poder”, en Instituciones y élites de poder en la monarquía hispana durante el siglo XVI, ed. José Martínez Millán (Madrid: Universidad Autónoma de Madrid, 1992), 14. El mismo autor analiza más ampliamente el papel de la corte como elemento articulador de las monarquías modernas y como lugar de encuentro entre gobernantes y gobernados en su "Introducción" a La monarquía de Felipe II: la casa del rey, dirs. José Martínez Millán y Santiago Fernández Conti (Madrid: Fundación Mapfre Tavera, 2005), I, 17-51.

${ }^{4}$ Antonio Álvarez-Ossorio Alvariño, "La corte: un espacio abierto para la historia social", en La historia social en España: actualidad y perspectivas, coord. Santiago Castillo (Madrid: Siglo XXI, 1991), 256.

${ }^{5}$ Christian Büschges, "La corte virreinal en la América hispánica durante la época colonial", en Actas del XII congreso internacional de AHIL A, América Latina: outro occidente? Debates do final do milenio, coords. Christian Büschges y Pilar Latasa (Oporto: Centro Leonardo Coimbra de Facultad de Letras, 2001), II, 133.
} 
una compleja red de consensos sociales, culturales y políticos que integraba los diversos territorios en una monarquía común ${ }^{6}$. De ahí que, como señala el autor citado, desde fines del siglo XVI la Monarquía Hispánica se contemplaba como una entidad política plural, un conglomerado de reinos sin más identidad común que la de obedecer a un mismo soberano y profesar la misma confesión. Más que una relación de centro a periferia, se trataba de un conjunto de cortes (microcosmos) vinculado con la monarquía (macrocosmos) ${ }^{7}$.

Mi interés por el tema nació a raíz de mi participación en un seminario sobre cortes virreinales en el mundo moderno que, bajo la dirección del profesor Manuel Rivero, se celebró en la Universidad Autónoma de Madrid en noviembre de 2011. Bajo el tema «Manila, corte de Filipinas», mi disertación se inició con el examen de la voz «corte», término polisémico que puede indicar ora un espacio material, la residencia del rey, ora uno social, el lugar donde se moviliza el entourage, el entorno o «casa extendida» del rey; ya un espacio temporal, el acto de tener corte (besamanos, cumplimientos), ya un ámbito comunicativo sujeto a un modo reglado de comportamiento (la cortesía) y donde un rígido ceremonial hace tangible el poder del rey, figura presente en la corte madrileña pero ausente en las virreinales; $y$, por último, la corte es también un espacio político: configura la estructura institucional del poder o, más en general, el centro focal de la política real ${ }^{8}$. En definitiva y según Büschges, la corte debe ser entendida como «un punto de contacto entre el príncipe y sus súbditos, como un espacio político, social y económico que sirve como foro de luchas y decisiones políticas, como mercado de oficios y privilegios y otras mercedes reales y, no en último lugar, como teatro de la representación del rey y del orden socio-político en general» mediante el uso de un rígido ceremonial'.

Por otra parte, podría decirse que las cortes virreinales eran un espejo de la corte real y el virrey, el alter ego del monarca, si bien con la excepción de que, a diferencia de éste, el poder del vicario real estaba limitado tanto por las instrucciones que le entregaban antes de partir, como por una posible visita de inspección y, en última instancia, por el juicio de residencia al que estaba sujeto al finalizar su mandato.

\footnotetext{
${ }^{6}$ Manuel Rivero Rodríguez, La edad de oro de los virreyes: el virreinato en la monarquía hispánica durante los siglos XVI y XVII (Madrid: Akal, 2011), 22.

7 Ibídem, 133.

8 Büschges, "La corte virreinal", 136. Martínez Millán, "La corte”, 28.

${ }^{9}$ Büschges, "La corte virreinal", 132. Por su parte, Latasa Vassallo señala que la corte virreinal, «compuesta por el virrey y sus criados, era un lugar de representación de la soberanía tanto hacia el interior, mediante la etiqueta de la jerarquía cortesana, como hacia el exterior a través del arte -efímero y permanente- y los actos públicos. Un compensado equilibrio entre boato, emblemática, retórica y escenografía que lograba transmitir con eficacia el mensaje deseado». Pilar Latasa Vasallo, "La corte virreinal peruana: perspectivas de análisis (siglos XVI y XVII)", en El gobierno de un mundo: virreinatos y audiencias en la América hispánica, coord. Feliciano Barrios (Cuenca: Universidad de Castilla-La Mancha, 2004), 353.
} 
Además, otros poderes locales (audiencia, cabildo, oficiales reales, Iglesia, Inquisición) servían de contrapoder al defender sus propios intereses ${ }^{10}$.

Un repaso a la bibliografía existente sobre las cortes virreinales de la Monarquía Hispánica nos revela que los estudios sobre las americanas llevan un cierto retraso respecto a los de sus pares europeas. Aunque ya Octavio Paz llamara la atención sobre la existencia de una corte virreinal en México en un libro dedicado a sor Juana Inés de la Cruz publicado en 1982 ${ }^{11}$, fueron Pilar Latasa y Christian Büschges quienes en 2001 abrieron la discusión e incluso propusieron líneas de investigación futura, tales como la reconstrucción de la familia del virrey y de sus redes clientelares, el análisis de las relaciones de poder entre el virrey y las instituciones administrativas coloniales, el diseño de un sistema de representación del orden socio-político y la configuración de un espacio de influencia cultural y de mecenazgo ${ }^{12}$. Aunque disponemos para las Indias con algunos valiosos trabajos sobre estas temáticas ${ }^{13}$, la investigación sobre las cortes virreinales americanas se ha enfocado prioritariamente en las fiestas y ceremonias públicas celebradas en las capitales de la Nueva España y el Perú. Y si bien es cierto que faltan más estudios sobre las cortes de México y Lima, también lo es que un camino apenas desbrozado lo constituyen los territorios provinciales -o centros periféricosque englobaban ambos virreinatos, pero sobre los cuales ya comenzamos a contar con algunas sólidas investigaciones.

¿Estos centros periféricos eran también cortes? En general la historiografía tradicional consideró que en el mundo indiano únicamente México y Lima respondían a tal categoría, en su caso cortes virreinales, ya que en ellas residía un virrey con la categoría de alter ego del monarca. ¿Pero existían también otras cortes, a las que podríamos denominar provinciales o periféricas? Para responder a esta pregunta hay que puntualizar que los territorios de ambos virreinatos eran inmensos, motivo por el que fueron divididos en una serie de "provincias mayores» en cada una de las cuales había un gobernador, una Audiencia, un cabildo y toda una serie de notables locales. $\mathrm{Y}$ al igual que el monarca hispano nunca visitó sus posesiones indianas, los virreyes de México y Lima tampoco visitaron, salvo excepciones, sus diversas provincias, lo que motivó que se dieran grandes poderes a los gobernadores provinciales, quienes, en última instancia, representaban la idea de la monarquía en sus respectivos territorios. El caso extremo es Filipinas: se trata de una provincia mayor dependiente del virreinato

${ }^{10}$ Büschges, "La corte virreinal", 134.

${ }^{11}$ Octavio Paz, Sor Juana Inés de la Cruz o las trampas de la fe (Barcelona: Seix Barral, 1982).

12 Sobre ello ha vuelto Christian Büschges en "La corte virreinal como espacio político: el gobierno de los virreyes de la América hispánica entre monarquía, élites locales y casa nobiliaria”, en El mundo de los virreyes en las monarquías de España y Portugal, eds. Pedro Cardim y Joan-Lluís Palos (Madrid: Iberoamericana; Frankfurt: Vervuert, 2012), 319-343.

${ }^{13}$ Véase la bibliografía que presentamos en anexo sobre la Corte en Indias. A destacar el análisis comparativo entre la corte virreinal novohispana y la de los reyes de España llevado a cabo por Iván Escamilla González, "La corte de los virreyes", en La ciudad barroca, coord. Antonio Rubial García (México: FCE; Colegio de México, 2005), 371-406. 
de Nueva España, pero cuya distancia de la capital mexicana era colosal. Así pues, en los territorios ultramarinos los distintos gobernadores provinciales tuvieron la importante función de representar al rey lejano y ausente en todo tipo de fiestas y ritos políticos.

$\mathrm{Si}$ analizamos los centros provinciales, observamos que responden a las definiciones de corte anotadas anteriormente. En primer lugar, el gobernador viajaba y se rodeaba de familiares, criados y sirvientes; o sea, el gobernador encabezaba un aparato doméstico que ocupaba el «palacio real», centro de la vida social y política y lugar donde residía el vicario del monarca ${ }^{14}$. En segundo lugar, el gobernador ejercía el patronaje real, lo que le aseguraba lealtades personales y el apoyo para la monarquía. $\mathrm{Al}$ repartir favores creaba en torno suyo, tal como en otra dimensión hacían los reyes y los virreyes, una red local de clientes, protegidos y cómplices, a quienes utilizaba como señala Iván Escamilla para los virreyes novohispanos- para encubrir su participación en lucrativos e ilícitos negocios y empresas ${ }^{15}$. Y en tercer lugar, el gobernador representaba al rey ausente durante las fiestas y ceremonias públicas, siguiendo un ceremonial que emulaba el de las cortes virreinales. Ciertamente, las fiestas y ceremonias que tenían lugar en las cortes provinciales carecían del lujo de las celebradas en México y Lima, pero eran muy semejantes en forma y fondo.

Por tanto, las amplias facultades dadas a los gobernadores provinciales les convertían en el principal intermediario entre el rey y los anhelos de la élite criolla local. $\mathrm{Y}$ asumiendo un papel fundamental en las ceremonias públicas, se manifestaban como cabeza de la comunidad respectiva, al tiempo que vinculaban el territorio bajo su mando con la monarquía y mediaban en los conflictos que surgían entre las distintas corporaciones locales. En otras palabras, los centros provinciales eran espacios donde se ponía de manifiesto la unidad de la Monarquía Hispánica, a la par que actuaban como poderosos mecanismos de legitimación y propaganda del poder real.

\section{LAS FIESTAS CORTESANAS}

Señalamos anteriormente que, de todas las temáticas relativas a la polisémica voz de Corte, la investigación americanista se ha volcado en el análisis de las fiestas cortesanas celebradas en las capitales virreinales mexicana y limeña. Por fiesta -en general- hay que entender un complejo cultural que ha sido definido por Miguel Roiz como una serie de acciones llevadas a cabo por un grupo, expresadas por medio de ritos y ceremonias que transmiten significados de diverso tipo (históricos, políticos, sociales, religiosos, etc.), en las que la práctica festiva de goce y diversión se

\footnotetext{
14 Pese a que el rey nunca residió en ellas, las residencias virreinales y provinciales se denominaban «palacios reales», ya que -como señala Rivero Rodríguez (La edad de oro, 161)- encarnaban la presencia del rey y constituían el centro de la vida social y política de los distintos territorios, la manifestación viva de la corte y el lugar donde residía la autoridad del monarca.

${ }^{15}$ Escamilla González, "La corte de los virreyes", 379.
} 
entremezcla con lo religioso e incluso mágico, cumpliendo determinadas finalidades culturales básicas para el grupo (tales como la cohesión y la solidaridad) y, por último, con un carácter extraordinario aunque anualmente circular $^{16}$. Contrapunto del trabajo y de la tensión cotidiana, el sentido básico de la fiesta es liberar al individuo de la rutina diaria.

Dentro de la gran diversidad de fiestas podemos distinguir, por un lado, la popular, sujeta al calendario anual y en la que participan amplios sectores sociales, tales como el carnaval (fiesta de invierno), la cruz de mayo y San Juan Bautista (primavera), fiestas de la cosecha o patronales y Corpus Chisti (verano-otoño), etc. ${ }^{17}$; y de otro, la fiesta cortesana, de carácter ocasional o extraordinario ${ }^{18}$, emanada del poder con una finalidad muy precisa y dotada de una gran espectacularidad y barroquismo; de ahí la usual denominación de las fiestas cortesanas como políticas y barrocas. Las motivaciones de estas fiestas extraordinarias son de carácter tanto civil como religioso. En efecto, unas están ligadas a la celebración de eventos que tienen como protagonistas, bien a miembros de la casa real (nacimientos de infantes, bodas, juras, exequias), bien a acontecimientos de la monarquía (celebración de victorias militares, firmas de tratados de paz); en cambio, otras responden a fenómenos religiosos tales como beatificaciones, canonizaciones, autos de fe, inauguración de un lugar sagrado, etc. En estas fiestas cortesanas, la participación del pueblo se limita a la contemplación pasiva.

La festividad cortesana ha atraído el interés de los investigadores de muy diversas disciplinas, pues en ella se hallan ligados el arte, la literatura, la emblemática, la mitología y la música ${ }^{19}$. La realidad española ha sido profusamente analizada, sobre todo la época de los Austrias, sin duda la de mayor esplendor. Esta proliferación de estudios pone de manifiesto la relevancia de la fiesta cortesana como atalaya desde la

\footnotetext{
${ }^{16}$ Miguel Roiz, "Fiesta, comunicación y significado", en Tiempo de fiesta: ensayos antropológicos sobre las fiestas en España, ed. Honorio M. Velasco (Madrid: Tres-Catorce-Diecisiete, 1982), 102-103.

${ }^{17}$ Sobre el ciclo festivo anual véase Salvador Rodríguez Becerra, "Las fiestas populares: perspectivas socio-antropológicas", en Homenaje a Julio Caro Baroja (Madrid: Centro de Investigaciones Sociológicas, 1978), 915-929. Asimismo José Manuel Gómez-Tabanera, "Fiestas populares y festejos tradicionales", en El folklore español, ed. J.M. Gómez-Tabanera (Madrid: Instituto Español de Antropología Aplicada, 1968), 149-216. La fiesta del Corpus ha recibido el interés de un elevado número de investigadores, tal y como puede verse en el amplio elenco bibliográfico recogido en La fiesta del Corpus Christi, coords. Gerardo Fernández Juárez y Fernando Martínez Gil (Cuenca: Universidad de Castilla-La Mancha, 2002), 519-544.

${ }^{18}$ Fiestas repentinas o súbitas las llamó el franciscano Juan de Torquemada en el libro X, capítulo VIII (intitulado "De las diversidades de fiestas que en las repúblicas se celebran, y en qué manera se instituyeron") de su obra Monarquía indiana (Sevilla: 1615; México: UNAM, Instituto de Investigaciones Históricas, 1975-1983, 7 v.). Citado en Angel López Cantos, Juegos, fiestas y diversiones en la América española (Madrid: Mapfre, 1992), 20-22.

${ }^{19}$ Una amplia bibliografía sobre la fiesta cortesana en Europa y España ha sido recogida por Bernardo García en La fiesta cortesana en la época de los Austrias, coords. María Luisa Lobato y Bernardo J. García García (Valladolid: Junta de Castilla y León, 2003), 293-377.
} 
que observar el funcionamiento de la sociedad ${ }^{20}$. A la par, las investigaciones sobre las fiestas cortesanas han mostrado que éstas eran espacios donde se hacía la política, no un simple ropaje externo a ella. El ritual que encierra cada celebración se contempla no como una mera función expresiva, sino como una herramienta del poder. Y, como tal herramienta, la historiografía ha demostrado que las fiestas y ceremonias reales cumplían eficazmente varios objetivos políticos. Eran armas de difusión ideológica, pues a través de ellas los gobernantes desarrollaban una importante labor pedagógica y propagandística; exaltaban la monarquía, legitimando la presencia de ésta como garante del orden social; fortalecían los vínculos entre el rey y sus reinos; a través de la fiesta, la sociedad mostraba su lealtad y acatamiento al sistema político; actuaban como mecanismo de cohesión social y, al mismo tiempo, manifestaban la reputación y el rango que ocupaba cada uno de los individuos, grupos y corporaciones presentes en el cuerpo político de la monarquía; en otras palabras, la fiesta era un reflejo de los principios jerárquicos que definían la sociedad. Y sobre todo en las Indias, las fiestas reales eran también un instrumento de occidentalización. Como señala Víctor Mínguez, podría decirse que las fiestas, los ritos y las ceremonias, más la decoración que se desplegaba en torno a ellas, construían un espacio en el que la propaganda y la ideología monárquica se materializaban en clave apoteósica ${ }^{21}$.

Si bien la historiografía ha evidenciado el papel de la fiesta como herramienta del poder, resulta pertinente interrogarnos sobre qué tipo de herramienta hablamos. Hace unos años, el politólogo norteamericano Joseph S. Nye acuñó los términos « poder blando» (soft power) y «poder duro» (hard power) como forma de diferenciar la sutil capacidad de persuasión y atracción de la cultura, valores e ideas de un país frente a la coacción brutal de la presión militar y económica ${ }^{22}$. Aplicando este concepto a la Monarquía Hispánica, podría decirse que el «poder duro» estaría representado por la fuerza de sus diferentes cuerpos castrenses y del «real de a ocho», mientras que el «poder blando» radicaría en el prestigio de su cultura y, sobre todo, en sus fiestas y ceremonias políticas (nacimientos de príncipes, bodas y exequias reales, entradas de

\footnotetext{
${ }^{20}$ Diversos trabajos recogen el estado de la cuestión y las líneas de investigación sobre la fiesta cortesana en la España del Antiguo Régimen. Roberto J. López, "Ceremonias y poder en el Antiguo Régimen: algunas reflexiones sobre fuentes y perspectivas de análisis", en Imagen del rey, imagen de los reinos: las ceremonias públicas en la España Moderna, dirs. Agustín González Enciso y Jesús M. Usunáriz Garayoa (Pamplona: EUNSA, 1999), 19-61. Santiago Martínez Hernández, "Cultura festiva y pode en la monarquía hispánica y su mundo: convergencias historiográficas y perspectivas de análisis”, Studia Historica, Historia Moderna 31 (2009): 127-152. María Pilar Monteagudo Robledo, "Fiesta y poder: aportaciones historiográficas al estudio de las ceremonias políticas en su desarrollo histórico", Pedralbes: Revista d'Historia Moderna 15 (1995): 173-204. M. Gema Palomo Fernández y José Luis Senra Gabriel y Galán, "La ciudad y la fiesta en la historiografía castellana de la Edad Media: escenografía lúdico-festiva", Hispania 186 (Madrid, 1994): 5-36.

${ }^{21}$ Víctor Mínguez, "La fiesta política virreinal: propaganda y aculturación en el México del siglo XVII", en La formación de la cultura virreinal. II. El siglo XVII, eds. Karl Kohut y Sonia V. Rose (Madrid: Iberoamericana; Frankfurt, Vervuert: 2004), 371.

${ }^{22}$ Joseph S. Nye, La paradoja del poder norteamericano (Madrid: Taurus, 2003), 30 y ss.
} 
virreyes, etc.), cuyo fin sería homogeneizar a todos los súbditos en torno a un referente político común.

Sin duda, más que mediante el «poder duro», la dominación colonial y la legitimación del poder y de sus autoridades delegadas se realizaron en Indias sobre el marco subjetivo de los mecanismos persuasivos, en los cuales jugaron un papel esencial las fiestas políticas. El rol de éstas como estrategias persuasivas del poder ha sido examinado por el profesor chileno Jaime Valenzuela Márquez, quien reflexiona -en un estudio modélico de antropología del ritual- sobre aquellos elementos profundos que sostienen el aparato ideológico de control social y que alimentan los contenidos de legitimación colectiva de la autoridad. Una legitimación que, para él, pasa fundamentalmente por los «meandros persuasivos» del gesto, de la presencia ostentatoria, de la palabra teatralizada, de la magnificencia sensual, de la apelación a la emoción y a la admiración, etc. ${ }^{23}$ Con respecto a esto último, Valenzuela Márquez, siguiendo a Clifford Geertz, resalta la importancia de las emociones y los sentimientos en tanto que «artefactos culturales»; de ahí que las liturgias y los eventos festivos se sirvieran del impacto emocional de sus formas y contenidos, apelando a la receptividad de la comunidad.

Merece la pena detenerse en la rica y compleja investigación de Valenzuela Márquez. Para el profesor chileno, el objetivo de los espectáculos litúrgicos era la persuasión, esto es, la generación de un marco subjetivo que permitiese la construcción de un «consenso» simbólico en la comunidad. Si el sistema lograba conseguirlo, la «opinión pública» estaría persuadida de la «naturalidad» de su existencia, de la legitimidad del ejercicio del poder y de los roles jugados por cada actor en su funcionamiento interno. De ahí que la búsqueda de dicho «consenso» simbólico se revele para dicho autor como una estrategia funcional a la dominación colonial a un nivel imperial y al control de la sociedad a nivel local ${ }^{24}$. Tal objetivo persuasivo se potencia con la participación de la Iglesia en la fiesta, en tanto que institución de poder e intermediaria de las fuerzas sobrenaturales ${ }^{25}$. Ambos universos, el civil y el religioso, a pesar de sus frecuentes conflictos internos, actúan de manera unívoca, compartiendo formas, contenidos y actores ${ }^{26}$. Y bajo el influjo estético del barroco, esta asociación de lo sagrado y lo civil aumenta el impacto emocional de las ceremonias y canaliza firmemente la persuasión política ${ }^{27}$.

\footnotetext{
${ }^{23}$ Jaime Valenzuela Márquez, Las liturgias del poder: celebraciones públicas y estrategias persuasivas en Chile colonial (1609-1709) (Santiago de Chile: Centro de Investigaciones Diego Barros Arana; DIBAM; Lom Editores 2001), 26. Para este autor (ibídem, 31), la «antropología del ritual» está destinada a estudiar las liturgias, incluyendo las fiestas oficiales, las ceremonias públicas y los ritos y símbolos de un amplio espectro sacro-profano, tanto desde su punto de vista morfológico como su «función social» e ideológica.

${ }^{24}$ Ibídem, 407.

${ }^{25}$ Ibídem, 30.

${ }^{26}$ Ibídem, 403.

27 Ibídem, 408.
} 
Hemos aludido al influjo estético del Barroco como método de persuasión, pero también de legitimación y propaganda. Para cumplir cabalmente estos fines, las celebraciones públicas fueron dotadas de una serie de elementos, entre los cuales hay que citar, en primer lugar, el arte efímero, en el que cabe destacar entre otros los arcos y carros triunfales y los catafalcos funerarios, que servían de soporte a la parte textual de la fiesta: pinturas, esculturas, emblemas, jeroglíficos, poesías, etc. constituían verdaderos programas iconográficos, de capital importancia en las Indias, un mundo nuevo que había de ser ordenado según el modelo de la metrópoli ${ }^{28}$. De ahí la relevancia de los estudios de emblemática para descubrir los significados simbólicos del lenguaje icónico-literario utilizado en el arte efímero ligado a las fiestas cortesanas ${ }^{29}$.

El elemento estético se potenciaba con los denominados «sonidos del poden», destinados a captar la atención y la admiración de la sociedad. Son los repiques de campanas, un lenguaje religioso que anuncia el inicio de la celebración; los disparos de armas de fuego, que apelan al simbolismo militar y al control colonial; la pirotecnia, reservada a la clausura nocturna de la fiesta; y la música marcial, que ritmaba el desfile del cortejo ${ }^{30}$.

Con el fondo de esta artificiosa y exuberante escenografía, que transformaba teatralmente el espacio central de la ciudad, desfilaba un cortejo en el que los actores participantes -la sociedad corporativa al completo- mostraban visualmente el lugar que jerárquicamente ocupaba cada uno. Una de sus paradas era la catedral, donde tenía lugar el Tedeum y el sermón, ceremonias religiosas que canalizaban la persuasión política hacia la generación de un consenso simbólico en la comunidad. La pompa eclesiástica -en estas ceremonias el obispo usaba la capa, la mitra y el báculo- contribuía a aumentar el sentido espectacular de la ceremonia pública ${ }^{31}$. La fiesta política ${ }^{32}$ finalizaba con una serie de eventos lúdicos -corridas de toros, juegos caballerescos,

${ }^{28}$ Fernando Checa, “Arquitectura efímera e imagen del poder", en Sor Juana y su mundo: una mirada actual, ed. Sara Poot Herrera (México: Universidad del Claustro de Sor Juana; FCE, 1995), 255.

${ }^{29}$ La producción historiográfica sobre la emblemática, un lenguaje que combina sutilmente literatura e imagen con un sentido moral y virtuoso, ha merecido sendas revisiones historiográficas. La primera fue realizada por Sagrario López Poza, "Los estudios sobre emblemática: logros, perspectivas y tendencias de investigación”, SIGNO. Revista de Historia de la Cultura Escrita 6 (1999): 81-95. La segunda, ceñida al mundo novohispano, es obra de Bárbara Skinfill Nogal, "Los caminos de la emblemática novohispana: una aproximación bibliográfica", en Las dimensiones del arte emblemático, eds. Bárbara Skinfill Nogal y Eloy Gómez Bravo (Zamora, Michoacán: El Colegio de Michoacán; Consejo Nacional de Ciencia y Tecnología, 2002), 45-72.

30 Valenzuela Márquez, Las liturgias del poder, 363-373.

31 Ibídem, 182-189.

32 Valenzuela Márquez (Las liturgias del poder, 31) la define como «una forma elaborada de ritual, una liturgia cívico-religiosa constituida por ceremonias solemnes en el templo y en otros espacios urbanos cargados de simbolismo, con procesiones o cortejos laicos, etc. Todo ello sin olvidar los eventos lúdicos más o menos profanos, los ruidos apoteósicos y las iluminaciones nocturnas extraordinarias. Las diversiones públicas juegan un papel importante no sólo porque aportan el atractivo de un gozo colectivo -aparentemente inocuo-, sino también [...] porque apoyan los objetivos legitimantes de los actores del poder $[\ldots] \gg$. 
representaciones teatrales-, que aportaban el atractivo de un gozo colectivo y apoyaban los objetivos legitimantes de los actores del poder.

Otro elemento de la fiesta -aparte de su financiamiento a cargo de los propios de la ciudad, tema escasamente investigado, y la transformación urbana de la ciudad en un singular espacio escenográfico donde tenía lugar la representación del rito político- era la redacción de unas obras conocidas como Relaciones de sucesos ${ }^{33}$. Impresas o manuscritas ${ }^{34}$, estas obras no sólo conservaban la memoria de las celebraciones reales, sino que algunas fueron ilustradas con grabados que recogen las arquitecturas efímeras levantadas para la ocasión, las carrozas y las comitivas que desfilaban por la ciudad, etc. Escritas en prosa o en verso o en una combinación de ambos estilos, no son simples obras laudatorias llenas de fórmulas estereotipadas y tópicos, como las han tildado investigadores como Bonet Correa ${ }^{35}$, sino verdaderas piezas literarias de gran complejidad textual, hasta el punto de haber sido valoradas últimamente como un género histórico-literario propio ${ }^{36}$. Sin entrar en esta polémica, conviene destacar que las relaciones de sucesos no sólo preservaban el recuerdo de la celebración, sino que también perpetuaban el discurso político de la fiesta, explicaban los textos emblemáticos incorporados a las arquitecturas efímeras y propagaban los códigos que se habían de desplegar en ocasiones semejantes.

${ }^{33}$ Las profesoras de la Universidad de A Coruña Nieves Pena Sueiro y Sagrario López Poza dirigen la base de datos «Biblioteca Digital Siglo de Oro» (BIDISO), que contiene una nutrida colección de referencias bibliográficas sobre literatura emblemática, relaciones de sucesos, polianteas y otras publicaciones sobre la cultura y la literatura de los Siglos de Oro.

${ }^{34}$ Escasas son las editadas modernamente, entre las que cabe citar:

- Rodrigo de Carvajal y Robles, Fiestas de Lima por el nacimiento del príncipe Baltasar Carlos [Lima: 1632; ed. Francisco López Estrada (Sevilla: CSIC, 1950)].

- Francisco Cervantes de Salazar, Túmulo imperial de la gran ciudad de México. Descripción que escribió [...] del túmulo que levantó la ciudad de México en las exequias del emperador Carlos V, y de las procesiones y ceremonias que con tal motivo se celebraron [México: 1560; reeditada en la obra México en 1554 y túmulo imperial, ed. Edmundo O’Gorman (México: Porrúa, 1963), 173-212].

- "Fiestas celebradas en Quito cuando la católica majestad de Carlos $3^{\circ}$ pasó del trono de Nápoles al de España, celebradas el año de 1760", Museo Histórico, año V, no 17 (1953): 126-148. Consta de dos partes: la primera es la relación, firmada el 22 de agosto de 1760 por el escribano público Juan Crisóstomo de León, del desarrollo de la fiesta y, la segunda, una loa para el primer carro triunfal que participó en la fiesta real. La primera parte y un breve resumen de la segunda se publicaron previamente en la misma revista quiteña bajo el título de "Interesantes relatos de las ceremonias realizadas en Quito por la muerte de Fernando Sexto y la exaltación al trono del rey Carlos Tercero", Museo Histórico, año I, $\mathrm{n}^{\circ} 1$ (1949): 7-15.

- Pedro Ximena, Reales exequias por el señor D. Carlos III, rey de las Españas y Américas, y real proclamación de su augusto bijo el señor D. Carlos IV por la muy noble y muy leal ciudad de Granada, provincia de Nicaragua, reyno de Guatemala [Impreso, 1793; ed. Manuel Ignacio Pérez Alonso (Managua: Banco Central de Nicaragua, 1974)].

- Fernando Montesinos, Auto de la fe, celebrado en Lima a 23 de enero de 1639, ed. Marta Ortiz Canseco (Madrid: Iberoamericana, 2016).

35 Antonio Bonet Correa, "La fiesta barroca como práctica del poder", en El arte efímero en el mundo hispánico (México: UNAM, Instituto de Investigaciones Estéticas, 1983), 43-84.

${ }^{36}$ Dalmacio Rodríguez Hernández, Texto y fiesta en la literatura novobispana (México: UNAM, Instituto de Investigaciones Bibliográficas, 1998), 119 y ss. 
Las relaciones de las fiestas celebradas en la corte real circulaban por todos los territorios de la Monarquía Hispánica, incluidas las Indias. Como es lógico, la plasmación de dichas fórmulas no fue uniforme. Si nos atenemos a las Indias y según nos cuentan las relaciones de sucesos editadas en sus diferentes imprentas, en las capitales virreinales de México y Lima la presencia de un virrey y la existencia de una próspera economía minera hicieron posible una reproducción bastante elaborada de los modelos peninsulares; en cambio, en territorios periféricos el modelo original se vio más afectado tanto por el menor peso relativo de sus respectivas autoridades como por sus más limitados recursos económicos. No obstante y aunque los modelos eran peninsulares, en Indias hubo margen para incorporar elementos propios de la realidad americana -v.g. y como señala Marina Alfonso Mola, la participación en los cortejos procesionales de caciques y cofradías de negros y mestizos ${ }^{37}$-, a la par que, inversamente, elementos americanos entraron a formar parte de la iconografía de las fiestas metropolitanas ${ }^{38}$.

Como es natural, en la América hispana se celebraron fiestas cortesanas por los mismos motivos que en la metrópoli. La mayor parte estaban vinculadas a eventos relacionados con miembros de la casa real, tales como nacimientos de infantes, bodas, proclamaciones o juras, onomásticas y exequias. Puede resultar paradójico que estas últimas sean consideradas como una fiesta más, en este caso una "fiesta de la muerte», pero no hay que olvidar que en el Barroco existió una glorificación de la muerte, de tal modo que el fallecimiento de un monarca era motivo para la realización de ritos y ceremonias muy elaboradas. Así, se levantaban túmulos en el interior de los templos, se organizaban cortejos fúnebres y actos litúrgicos -misas, sermones- que se convertían en una afirmación del poder monárquico.

Otra celebración dinástica tenía lugar con ocasión de las entradas de los reyes en las ciudades de sus diferentes reinos. Sin embargo y por razones fácilmente entendibles, ninguna urbe indiana fue visitada por monarca alguno; de ahí que en las entradas celebradas en Indias el protagonista no fuera el monarca sino su alter ego. Ello no obsta para que estas ceremonias fueran una fiesta política de primer orden, pues en ellas se renovaban los vínculos de unión entre el rey ausente y sus súbditos a través de la figura de su vicario. Elemento fundamental en las entradas eran los arcos triunfales,

${ }^{37}$ Marina Alfonso Mola, "Fiestas en honor de un rey lejano: la proclamación de Felipe V en América", en Felipe V y el Atlántico, coord. Antonio Béthencourt Massieu (Las Palmas de Gran Canaria: Cabildo de Gran Canaria, 2002), 261. Sobre la americanización de la iconografía, reveladora de la aparición de una conciencia de identidad americana, véase Karine Périssat, "Las representaciones del espacio americano en las fiestas limeñas de la época colonial”, Criticón 78 (2000): 29-43.

38 Andrea Sommer-Mathis et alii, El teatro descubre América: fiestas y teatro en la Casa de Austria (14921700) (Madrid: Mapfre, 1992). Los autores de esta obra se plantean la cuestión de las formas de representación y recepción de América en Europa, especialmente en las fiestas y en las artes en el ámbito de la Casa de Austria. La utilización de alegorías del Nuevo Mundo en las fiestas cortesanas era la manera más espectacular de dar a entender el derecho de la dinastía de los Habsburgo a sus dominios ultramarinos. 
soportes de un programa iconográfico que consistía en la alabanza de la persona del vicario real, a la que se relacionaba con varones heroicos o semidioses. A destacar, en el contexto de la americanización de la iconografía del Nuevo Mundo a la que me referí con anterioridad, el arco de triunfo «aindiado» elaborado, por encargo del cabildo mexicano, por el intelectual criollo Carlos de Sigüenza y Góngora con motivo de la entrada en la ciudad de México del virrey conde de la Laguna el día 30 de noviembre de 1680. En él colocó a los antiguos gobernantes del México prehispánico como modelos de «buen gobierno» para el príncipe cristiano, de tal manera que, por un lado, reivindicaba a un pueblo vencido y dominado por los españoles y, por otro, aunaba simbólica y temporalmente a las naciones india y española en un todo unitario y armónico. Este programa iconográfico era provocativo, ya que perseguía la homologación de los emperadores aztecas, que en el siglo XVII tenían el estigma de gente «bárbara» y demoníaca, con los príncipes cristianos. Como ha señalado Antonio Lorente, ello no era sino un "paso ineludible para la reafirmación identitaria» de la comunidad criolla a la que pertenecía Sigüenza y Góngora ${ }^{39}$. Por otra parte hay que señalar, respecto a las entradas de los virreyes novohispanos, que su itinerario desde que desembarcaban en Veracruz hasta que entraban en la ciudad de México constituía, como ha señalado Octavio Paz, «una verdadera peregrinación ritual», que evidentemente ha de interpretarse como una alegoría política, pues las etapas importantes del viaje guardaban estrechísima relación con la conquista militar (Hernán Cortés) y espiritual (llegada de los «doce apóstoles») del mundo azteca ${ }^{40}$.

Asimismo, se celebraron en la América española otras fiestas ocasionales vinculadas a la monarquía. A destacar, por su impacto persuasivo, el auto de fe, una fiesta de complejas connotaciones jurídicas, religiosas y sociales y dotada de un ceremonial muy preciso, tal y como ha analizado Doris Moreno ${ }^{41}$. Sin embargo, esta fiesta, así como las celebradas con motivo de victorias militares, el recibimiento del sello real en las reales audiencias, beatificaciones y canonizaciones, han recibido escaso interés por los investigadores de la realidad americana. Todo lo contrario que la fiesta sacramental del Corpus Christi. Aunque es una celebración anual, aúna elementos de la fiesta cortesana y de la popular. En efecto, en la procesión está presente toda la sociedad corporativa del Antiguo Régimen, donde cada grupo ocupa el lugar prefijado a su estatus y calidad y, presidiendo a todos, la máxima dignidad: el Santísimo Sacramento. Pero a la par, en el cortejo aparecen también los enemigos de Dios y de la Iglesia -demonios y herejes-, representados por figuras grotescas como la tarasca. Como señala Díez Borque, el Corpus era una fiesta popular pero organizada y dirigida desde arriba, a la par que totalizadora desde el momento que integraba ceremonias, autos sacramentales, danzas y olores (incienso, flores), elementos todos ellos que

\footnotetext{
${ }^{39}$ Antonio Lorente Medina, La prosa de Sigüenza y Góngora y la formación de la conciencia criolla mexicana (Madrid: UNED; FCE, 1996), 11-15.

${ }^{40}$ Ibídem, 45. Paz, Sor Juana, 193-195.

${ }^{41}$ Doris Moreno Martínez, "Cirios, trompetas y altares: el auto de fe como fiesta", Espacio, Tiempo y Forma, Serie IV, Historia Moderna 10 (1997): 143-171.
} 
infundían a la procesión unas funciones de espectáculo y expansión lúdica que no quebrantaban, sino todo lo contrario, el sentido triunfante de la custodia eucarística ${ }^{42}$.

Para finalizar quisiera expresar tres reflexiones. La primera, que en el siglo XVIII americano la fiesta cortesana continuó siendo básicamente barroca ${ }^{43}$ y estando al servicio de la dinastía borbónica de igual manera que lo estuvo con su predecesora ${ }^{44}$; lo que sí hubo fue un mayor control y reglamentación de las diversiones públicas, tal como analizó hace unos años el profesor Viqueira Albán para la ciudad de México ${ }^{45}$. La segunda es el retraso de los estudios sobre fiestas cortesanas en Filipinas, la más oriental de las cortes provinciales de la Monarquía Hispánica, sobre las que quien esto firma está trabajando actualmente. La última reflexión tiene que ver con el papel de la fiesta política en el movimiento emancipador que sacudió a la América hispana a partir de 1810: aunque su finalidad fue la de crear una identidad nacional en las nuevas naciones que se estaban independizando, los estudios realizados sobre las primeras «fiestas patrias» muestran continuidades y rupturas respecto a las celebraciones monárquicas de la época colonial. Como ha señalado Pablo Ortemberg, si bien en la Francia revolucionaria el lenguaje ritual buscó la innovación, los pueblos americanos pretendieron, por el contrario, legitimar su autonomía y sancionar la nueva era con rituales que presentaban importantes rasgos de continuidad con sus antecedentes coloniales $^{46}$. Añoranzas del pasado para tiempos nuevos ${ }^{47}$.

42 José María Díez Borque, "Fiesta popular, cortesana y sacramental en la época de Calderón de la Barca”, en El Madrid de Velázquezy Calderón. Villa y corte en el siglo XVII. I. Estudios históricos, eds. Miguel Morán Suriana y Bernardo J. García García (Madrid: Ayuntamiento de Madrid; Fundación Caja Madrid, 2000), 253-276, especialmente 271-273.

${ }^{43}$ Un autor lo ha achacado al hecho de que en América no hubo Ilustración. Rafael Ramos Sosa, "La fiesta barroca en Ciudad de México y Lima", Historia 30 (1997): 263-286, especialmente 265.

${ }^{44}$ Monteagudo Robledo, "Fiesta y poder", 196-203.

${ }^{45}$ Juan Pedro Viqueira Albán, ¿Relajados o reprimidos?: diversiones públicas y vida social en la ciudad de México durante el Siglo de las Luces (México: FCE, 1987).

46 Pablo Ortemberg, "Sentidos e historia de las fiestas patrias: una introducción", en El origen de las fiestas patrias: Hispanoamérica en la época de la Independencia, dir. Pablo Ortemberg (Rosario, Argentina: Prohistoria Ediciones, 2013), 11-25. Para la fiesta republicana en Francia véanse los estudios de Olivier Ihl, La fête républicaine (París: Gallimard, 1996). Mona Ozouf, La fête révolutionnaire, 1789-1799 (París : Gallimard, 1976). Rosemonde Sanson, Les 14 juillet, 1789-1975, fête et conscience nationale (París: Flammarion, 1976). Michel Vovelle, Les métamorphoses de la fête en Provence de 1750 à 1820 (París: AubierFlammarion, 1976); del mismo autor, "De la fiesta tradicional al Estado moderno: la metamorfosis de la fiesta en Francia", en Fiesta y nación en Colombia, autor-comp. Marcos González Pérez (Bogotá: Cooperativa Editorial Magisterio, 1998), 13-26. Gilbert Ziebura, "Francia en 1790 y 1794: la fiesta como acto revolucionario", en La fiesta: una historia cultural desde la Antigüedad hasta nuestros días, dir. Uwe Schultz (Madrid: Alianza, 1993), 255-269.

${ }^{47}$ Lo mismo sucedió en otras manifestaciones festivas. Véase por ejemplo Germán Viveros, “Corpus Christi en 1853: añoranza poética mexicana", en La literatura novohispana: revisión crítica y propuestas metodológicas, eds. José Pascual Buxó y Arnulfo Herrera (México: UNAM, Instituto de Investigaciones Bibliográficas, 1994), 145-157. 
ANEXO

BIBLIOGRAFÍA SOBRE CORTE Y FIESTAS CORTESANAS EN LA AMÉRICA HISPANA ${ }^{48}$

A) LA CORTE

\section{ESTUDIOS GENERALES}

\section{LA CORTE EN INDIAS}

2.1. América general

2.2. México

2.3. Perú

2.4. Otros territorios

\section{B) LAS FIESTAS CORTESANAS}

\section{CONCEPTO DE FIESTA}

\section{ELEMENTOS DE LA FIESTA}

2.1. Arte efímero

2.2. Emblemática

2.3. Pirotecnia

2.4. Tedeum

2.5. Relaciones de sucesos

3. ESTUDIOS GENERALES ${ }^{49}$

3.1. América general

3.2. México

3.3. Perú

3.4. Otros territorios

\section{CELEBRACIONES DINÁSTICAS}

4.1. Natalicios

$$
\text { 4.1.1. México }
$$

\footnotetext{
48 Avisamos al lector que la bibliografía que ofrecemos de estudios generales sobre la Corte, al no ser el objetivo del presente artículo, constituye una breve selección orientativa; en cambio, la relativa a las cortes virreinales americanas y las fiestas políticas que tuvieron lugar en ellas procura la exhaustividad, objetivo de tan díficil alcance que excusa posibles omisiones. El elevado número de referencias que presentamos nos ha llevado a estructurar la presente bibliografía, excepto la correspondiente al concepto de fiesta y a los elementos de ésta, en una división cuatripartita: estudios generales a todas -o parte delas Indias hispanas, virreinato de México, virreinato del Perú y otros territorios.

${ }^{49}$ Contiene trabajos que abarcan varias áreas geográficas o más de un tipo de festividad en una de ellas.
} 
4.1.2. Perú

4.1.3. Otros territorios

4.2. Bodas

4.2.1. América general

4.3. Juras y proclamaciones

4.3.1. América general

4.3.2. México

4.3.3. Perú

4.3.4. Otros territorios

4.4. Cumpleaños

4.4.1. México

4.5. Exequias y honras fúnebres

4.5.1. Estudios generales

4.5.2. México

4.5.3. Perú

4.5.4. Otros territorios

5. LAS ENTRADAS DEL ALTER EGO DEL REY AUSENTE

5.1. América general

5.2. México

5.3. Perú

5.4. Otros territorios

\section{OTRAS CELEBRACIONES EXTRAORDINARIAS}

6.1. Autos de fe

6.1.1. México

6.1.2. Perú

6.2. Recibimientos del sello real

6.2.1. América general

6.2.2. Perú

6.2.3. Otros territorios

6.3. Victorias militares

6.3.1. América general

6.3.2. México

6.4. Beatificaciones y canonizaciones

6.4.1. México

6.4.2. Perú

6.4.3. Otros territorios

6.5. Otras fiestas extraordinarias

\section{LA FIESTA SACRAMENTAL DEL CORPUS CHRISTI}

7.1. América general

7.2. México

7.3. Perú 
7.4. Otros territorios

\section{FIESTAS CORTESANAS EN LAS ISLAS FILIPINAS}

\section{DE LAS FIESTAS MONÁRQUICAS A LAS FIESTAS CÍVICAS DE LAS NUEVAS PATRIAS}

9.1. América general

9.2. México

9.3. Perú

9.4. Otros territorios

\section{A) LA CORTE}

\section{ESTUDIOS GENERALES}

ÁLVAREZ-OSSORIO ALVARIÑO, Antonio. "La corte, un espacio para la historia social". En Santiago Castillo (coord.), La historia social en España: actualidady perspectivas. Actas del I Congreso de la Asociación de Historia Social, Zaragoza, septiembre, 1990. Madrid: Siglo XXI, 1991, pp. 247-260.

---- "Corte y cortesanos en la monarquía de España". En Georgia Patrizi y Amadeo Quodam (eds.), Educare il corpo, educare la parola nella tratadistica del Rinascimiento. Roma: Bulzoni Editore, 1998, pp. 297-367.

DUINDAM, Jeroen. Viena y Versalles: las cortes de los rivales dinásticos europeos entre 1550 y 1780. Madrid: Antonio Machado Libros, 2009. (Papeles del Tiempo; 16).

ELIAS, Norbert. Elproceso de civilización: investigaciones sociogenéticas y psicogenéticas. México: FCE, 1993. (1ª ed. 1939).

---- La sociedad cortesana. Madrid: FCE, 1993. (1ª ed. 1969).

ELLIOT, John H. "La corte de los Habsburgo españoles: ¿una institución singular?”. En España y su mundo, 1500-1700. Madrid: Alianza, 1990, pp. 179-200.

---- "A Europe of composite monarchies". Past and Present 137:1 (Oxford University Press, 1992): 48-71.

GÓMEZ-CENTURIÓN JIMÉNEZ, Carlos. "La corte de Felipe V: el ceremonial y las casas reales durante el reinado del primer Borbón". En Antonio Béthencourt Massieu (ed.), Felipe V y el Atlántico. III Centenario del advenimiento de los Borbones. Coloquio de Historia Canario-Americana (14 . 2000. Las Palmas de Gran Canaria). Las Palmas de Gran Canaria: Cabildo de Gran Canaria, 2002, pp. 189-247. 
HERNANDO SÁNCHEZ, Carlos José. "La corte y las cortes de la monarquía". En Felipe II. Un monarca y su época. Las tierras y los hombres del rey. Valladolid: Sociedad Estatal para la Conmemoración de los Centenarios de Felipe II y Carlos V, 1998, pp. 71-79.

HESPANHA, Antonio M. "La corte". En La gracia del derecho. Economia de la cultura en la Edad Moderna. Madrid: Centro de Estudios Políticos y Constitucionales, 1993, pp. 177-202.

LISÓN TOLOSANA, Carmelo. La imagen del rey (monarquía, realeza y poder ritual en la Casa de los Austrias). Madrid: Espasa Calpe, 1992.

MARTÍNEZ MILLÁN, José. "Introducción. La investigación sobre las élites del poder". En José Martínez Millán (dir.), Instituciones y élites de poder en la monarquía bispana durante el siglo XVI. Madrid: Universidad Autónoma de Madrid, 1992, pp. 11 24.

---- "Las investigaciones sobre patronazgo y clientelismo en la administración de la monarquía hispana durante la Edad Moderna". Studia Historica. Historia Moderna 15 (Salamanca, 1996): 83-106.

---- “Introducción”. En José Martínez Millán y Santiago Fernández Conti (dirs.), La monarquia de Felipe II: la casa del rey. Madrid: Fundación Mapfre Tavera, 2005; vol. I, pp. 17-51.

---- "La corte de la monarquía hispánica". Studia Historica. Historia Moderna 28 (Salamanca, 2006): 17-61.

MARTÍNEZ MILLÁN, José (dir.). La corte de Felipe II. Madrid: Alianza Editorial, 1994. (Alianza Universidad; 798).

---- (dir.). La corte de Carlos V. Madrid: Sociedad Estatal para la Conmemoración de los Centenarios de Felipe II y Carlos V, 2000. 5 v.

---- y Santiago FERNÁNDEZ CONTI (dirs.). La monarquía de Felipe II: la casa del rey. Madrid: Fundación Mapfre Tavera, 2005. 2 v.

REDWORTH, Glyn y Fernando CHECA CREMANES. "The Court of Spanish Habsburgs, 1500-1700". En John Adamson (ed.), The Princely Courts of Europe: Rituals, Politics and Culture under the Ancien Regime, 1500-1700. Londres: Weidenfeld\&Nicolson, 1999, pp. 43-65. 
RIVERO RODRÍGUEZ, Manuel. La edad de oro de los virreyes: el virreinato en la monarquía hispánica durante los siglos XVI y XVII. Madrid: Akal, 2011.

RODRÍGUEZ VILLA, Antonio. Etiquetas de la casa de Austria. Madrid: Est. y Tip. de Jaime Retés, 1913.

SÁEZ-ARANCE, Antonio. "La corte de los Habsburgo en Madrid (siglos XVI y XVII): nuevas tendencias historiográficas". En Monika Bosse, Barbara Potthast y André Stoll (eds.), La creatividad femenina en el mundo barroco hispánico: María de Zayas, Isabel Rebeca Correa, Sor Juana Inés de la Cruz. Kassel: Edition Reichenberger, 1999; vol. I, pp. $1-16$.

\section{LA CORTE EN INDIAS}

\subsection{América general}

BUSCHGES, Christian. "La corte virreinal en la América hispana durante la época colonial". En Christian Büschges y Pilar Latasa (coords.), Actas del XII congreso internacional de AHILA. América Latina: outro occidente? Debates do final do milenio. Centro Leonardo Coimbra de Facultad de Letras, Oporto, 2001; vol. II, pp. 131-140.

---- "La corte virreinal como espacio político: el gobierno de los virreyes de la América hispánica entre monarquía, élites locales y casa nobiliaria”. En Pedro Cardim y Joan-Lluís Palos (eds.), El mundo de los virreyes en las monarquías de España y Portugal. Madrid: Iberoamericana; Frankfurt am Main: Vervuert, 2012. (Tiempo Emulado. Historia de América y España; 22); pp. 319-343.

CALVO, Thomas. "El rey y sus Indias: entre imagen y papel (siglos XVIXVIII)". En Oscar Mazín Gómez (ed.), México en el mundo hispánico. Zamora, Michoacán: El Colegio de Michoacán, 2000; vol. II, pp. 427-483.

CANTÚ, Francesca (ed.). Las cortes virreinales de la monarquía española: América e Italia. Actas del Coloquio Internacional Sevilla 1-4 junio 2005. Roma: Viella, 2008. (Studi e Ricerche; 17).

\subsection{México}

BUSCHGES, Christian. "El valido del virrey: poder, 'patronage' y clientelismo en la corte virreinal mexicana (1612-1635)". En Christian Büschges y Pilar Latasa (coords.), Actas del XII congreso internacional de AHILA. América Latina: outro occidente? Debates do final do milenio. Centro Leonardo Coimbra de Facultad de Letras, Oporto, 2001, vol. II, pp. 141-150. 
---- "Del criado al valido: el patronazgo de los virreyes de Nápoles y Nueva España (primera mitad del siglo XVII)". En Francesca Cantú (ed.), Las cortes virreinales de la monarquía española: América e Italia. Roma: Viella, 2008, pp. 157-181.

CAÑEQUE, Alejandro. "Cultura vicerregia y estado colonial: una aproximación crítica al estudio de la historia política de la Nueva España". Historia Mexicana vol. 201, no 51:1 (México, 2001): 5-57.

---- The King's Living Image: the Culture and Politics of Viceregal Power in Colonial Mexico. New York; London: Routledge, 2004.

---- "De sillas y almohadones o de la naturaleza ritual del poder en la Nueva España de los siglos XVI y XVII. Revista de Indias vol. 64, no 232 (Madrid, 2004): 609634.

---- "De parientes, criados y gracias: cultura del don y poder en el México colonial (siglos XVI-XVII)". Histórica 29:1 (Lima, 2005): 7-42.

CARMAGNANI, Marcello. "El virrey la corte virreinal en Nueva España”. En Francesca Cantú (ed.), Las cortes virreinales de la monarquía española: América e Italia. Roma: Viella, 2008, pp. 65-77.

ESCAMILLA GONZÁLEZ, Iván. "La corte de los virreyes". En Antonio Rubial García (coord.), La ciudad barroca. México: FCE; Colegio de México, 2005. (Historia de la vida cotidiana en México; 2), pp. 371-406.

LATASA VASSALLO, Pilar. "La corte virreinal novohispana: el virrey y su casa, imágenes distantes del rey y su corte (siglo XVII)". En Christian Büschges y Pilar Latasa (coords.), Actas del XII congreso internacional de AHIL A. América Latina: outro occidente? Debates do final do milenio. Centro Leonardo Coimbra de Facultad de Letras, Oporto, 2001, vol. II, pp. 115-130.

---- "La casa del obispo-virrey Palafox: familia y patronazgo. Un análisis comparativo con la corte virreinal hispanoamericana". En Ricardo Fernández Gracia (coord.), Palafox: Iglesia, cultura y Estado en el siglo XVII. Pamplona: Universidad de Navarra, 2001, pp. 210-228.

PAZ, Octavio. Sor Juana Inés de la Cruz o las trampas de la fe. Barcelona: Seix Barral, 1982.

PIETSCHMANN, Horst. "La corte virreinal de México en el siglo XVII en sus dimensiones jurídico-institucionales, sociales y culturales: aproximación al estado de la cuestión". En Monika Bosse, Barbara Potthast y André Stoll (eds.), La creatividad 
femenina en el mundo barroco hispánico: María de Zayas, Isabel Rebeca Correa, Sor Juana Inés de la Cru₹: Kassel: Edition Reichenberger, 1999; vol. II, pp. 481-497.

PORRAS MUÑOZ, Guillermo. "Viaje a Méjico del marqués de Montes Claros y 'Advertencias' para su gobierno”. Revista de Indias, vol. VIII, no 27 (Madrid, 1947): $117-126$.

RUBIAL GARCÍA, Antonio. "La corte virreinal". En A. Rubial García, La plaza, el palacio y el convento: la ciudad de México en el siglo XVII. México: Consejo Nacional para la Cultura y las Artes, 1998, pp. 83-92.

\subsection{Perú}

LATASA VASSALLO, Pilar. "La corte virreinal peruana: perspectivas de análisis (siglos XVI y XVII)". En Feliciano Barrios Pintado (coord.), El gobierno de un mundo: virreinatos y audiencias en la América hispánica. Cuenca: Universidad de Castilla-La Mancha; Fundación Rafael del Pino, 2004. (Coediciones; 32), pp. 341-373.

---- "Negociar en red: familia, amistad y paisanaje: el virrey Superonda y sus agentes en Lima y Cádiz (1745-1761)". Anuario de Estudios Americanos, vol. 60:2 (Sevilla, 2003): 463-492.

---- "Poder y favor en la corte virreinal del Perú: los criados del marqués de Montesclaros (1607-1615)". Histórica XXXVI:2 (Lima, 2012): 49-84.

MERLUZZI, Manfredi. "Il Perù del viceré Francisco de Toledo: l'affermazione di uno spazio politico cortigiano". En Francesca Cantú (ed.), Las cortes virreinales de la monarquía española: América e Italia. Roma: Viella, 2008, pp. 79-102.

TORRES ARANCIVIA, Eduardo. Cortes de virreyes: el entorno del poder en el Perú del siglo XVII. Lima: Fondo Editorial de la Pontificia Universidad Católica del Perú, 2006.

\subsection{Otros territorios}

BRIDIKHINA, Eugenia. "La ciudad y la corte como espacio de poder en Hispanoamérica: La Plata colonial”. Revista de Indias, vol. LXVII, no 240 (Madrid, mayoagosto 2007): 553-572 (DOI: http://dx.doi.org/10.3989/revindias.2007.i240).

BÜSCHGES, Chistian. "Las leyes del honor: honor y estratificación social en el distrito de la Audiencia de Quito". Revista de Indias, vol. LVII, no 209 (Madrid, 1997): 55-84 (DOI: http://dx.doi.org/10.3989/revindias.1997.i209). 
---- "Urban Public Festivals as Representations and Elements of Social Order in Colonial Ecuador". En Johannes-Michael Scholz y Tamar Herzog (eds.), Observation and Communication: the Construction of Realities in the Hispanic World. Frankfurt am Main: Klostermann, 1997, pp. 113-131.

HERZOG, Tamar. "La presencia ausente: el virrey desde la perspectiva de las élites locales (Audiencia de Quito, 1640-1747)". En Monarquía, imperio y pueblos de la España moderna. Actas de las IV reunión científica de la Asociación española de Historia Moderna (Alicante, 1996). Alicante: Caja de Ahorros del Mediterráneo; Universidad de Alicante, 1997; vol. I, pp. 819-826.

LEAL CURIER, Carola. El discurso de fidelidad: construcción social del espacio como simbolo del poder regio: (Venezuela, siglo XVIII). Caracas: Academia Nacional de la Historia, 1991.

URQUIZA, Fernando Carlos. "Etiquetas y conflictos: el obispo, el virrey y el cabildo en el Río de la Plata en la segunda mitad del siglo XVIII". Anuario de Estudios Americanos L:1 (Sevilla, 1993): 55-100.

\section{B) LAS FIESTAS CORTESANAS}

\section{CONCEPTO DE FIESTA}

ÁLVAREZ SANTALÓ, León Carlos. "Mensaje festivo y estética desgarrada: la dura pedagogía de la celebración barroca". Espacio, Tiempo y Forma. Serie IV. Historia Moderna, 10 (Madrid, 1997): 33-52.

---- "La fiesta barroca contada: una demostración retórica consciente". En Manuel Peña Díaz, Pedro Ruiz Pérez y Julián Solano Pujalte (eds.), La cultura del libro en la Edad Moderna. Andalucía y América. Córdoba: Universidad de Córdoba, 2001, pp. 47-84.

BONET CORREA, Antonio. "La fiesta barroca como práctica del poder". Diwan 5-6 (Zaragoza, 1979): 53-85. Reeditada en El arte efimero en el mundo bispánico. México: UNAM, Instituto de Investigaciones Estéticas, 1983. (Estudios de Arte y Estética; 17), pp. 43-84.

---- Fiesta, podery arquitectura: aproximaciones al barroco español. Madrid: Akal, 1990. (Arte y Estética; 22).

DÍEZ BORQUE, José María. "Fiesta popular, cortesana y sacramental en la época de Calderón de la Barca”. En Miguel Morán Suriana y Bernardo J. García García 
(eds.), El Madrid de Velárquezy Calderón. Villa y corte en el siglo XVII. I. Estudios históricos. Madrid: Ayuntamiento de Madrid; Fundación Caja Madrid, 2000, pp. 253-276.

GÓMEZ GARCÍA, Pedro. "Hipótesis sobre la estructura y función de las fiestas". En Pierre Cordoba y Jean Pierre Etienvre (eds.), La fiesta, la ceremonia, el rito. Coloquio internacional (Granada, 1987). Granada: Universidad de Granada; Casa de Velázquez, 1990, pp. 51-62.

LÓPEZ, Roberto J. "Ceremonias y poder en el Antiguo Régimen: algunas reflexiones sobre fuentes y perspectivas de análisis". En Agustín González Enciso y Jesús M. Usunáriz Garayoa (dirs.), Imagen del rey, imagen de los reinos: las ceremonias públicas en la España Moderna. Pamplona: EUNSA, 1999, pp. 19-61.

MARAVALL, José Antonio. La cultura del Barroco: análisis de una estructura histórica. $3^{\mathrm{a}}$ ed. Barcelona: Ariel, 1983. (1ª ed. 1975).

MARQUARD, Odo. "Pequeña filosofía de la fiesta". En Uwe Schultz (dir.), La fiesta: una historia cultural desde la Antigüedad hasta nuestros días. Madrid: Alianza, 1993, pp. 357-366.

MARTÍNEZ HERNÁNDEZ, Santiago. "Cultura festiva y poder en la monarquía hispánica y su mundo: convergencias historiográficas y perspectivas de análisis”. Studia Historica, Historia Moderna 31 (Salamanca, 2009): 127-152.

MÍNGUEZ, Víctor et alii (eds.). Ceremoniales, ritos y representación del poder. Castelló de la Plana: Universitat Jaume I, 2004.

MONTEAGUDO ROBLEDO, María Pilar. "Fiesta y poder: aportaciones historiográficas al estudio de las ceremonias políticas en su desarrollo histórico". Pedralbes: Revista d'Historia Moderna 15 (Barcelona, 1995): 173-204.

MUIR, Edward. Fiesta y rito en la Europa Moderna. Madrid: Editorial Complutense, 2001. (La Mirada de la Historia).

PIEPER, Josef. Una teoría de la fiesta. Madrid: Rialp, 1974. 2ª ed. 2006.

ROIZ, Miguel. "Fiesta, comunicación y significado". En Honorio M. Velasco (ed.), Tiempo de fiesta: ensayos antropológicos sobre las fiestas en España. Madrid: Tres-CatorceDiecisiete, 1982, pp. 95-150. 


\section{ELEMENTOS DE LA FIESTA}

\subsection{Arte efímero}

ANAYA LARIOS, José Rodolfo. Arquitectura efímera de Querétaro. Santiago de Querétaro, Querétaro: Gobierno del Estado de Querétaro, 1997.

El ARTE efimero en el mundo hispánico. México: UNAM, Instituto de Investigaciones Estéticas, 1983. (Estudios de Arte y Estética; 17).

BRAVO ARRIAGA, María Dolores. "El arco triunfal novohispano como representación”. En José Amezcua y Serafín González (eds.), Espectáculo, texto y fiesta: Juan Ruiz de Alarcón y el teatro de su tiempo. Iztapalapa, México: Universidad Autónoma Metropolitana, 1990. (Publicaciones del Departamento de Filosofía; 10), pp. 85-93.

CAÑEQUE, Alejandro. "Espejo de virreyes: el arco triunfal del siglo XVII como manual efímero del buen gobernante". En José Pascual Buxó (ed.), Reflexión y espectáculo en la América virreinal. Méxicio: UNAM, Instituto de Investigaciones Bibliográficas, 2007. (Estudios de Cultura Literaria Novohispana; 25), pp. 199-218.

CHECA, Fernando. “Arquitectura efímera e imagen del poder". En Sara Poot Herrera (ed.), Sor Juana y su mundo: una mirada actual. México: Universidad del Claustro de Sor Juana; Gobierno del Estado libre y soberano de Puebla; FCE, 1995, pp. 251 305.

HERRERA, Arnulfo. "La decadencia de la imaginación: el arco triunfal de don Antonio Deza y Ulloa”. Anales del Instituto de Investigaciones Estéticas 87 (México, UNAM, otoño de 2005): 7-35.

KÜGELGEN, Helga von. "The Way to Mexican Identity: Two Triumphal Arches of the XVIIth Century". En International Congress of the History of Art $\left(26^{\circ}\right.$. 1986. Washington). World Art: Themes of Unity in Diversity: Acts of the XXVIth International Congress of the History of Art. Philadelphia, Penn.: Pennsylvania State University Press, 1989, pp. 709-720.

LORENTE MEDINA, Antonio. La prosa de Sigüenza y Góngora y la formación de la conciencia criolla mexicana. Madrid: Universidad Nacional de Educación a Distancia; FCE, 1996.

MAZA, Francisco de la. La mitología clásica en el arte colonial de México. México: UNAM, Instituto de Investigaciones Estéticas, 1968. (Estudios y fuentes del arte en México; 24).

MÉNDEZ BAÑUELOS, Sigmund Jádmar. "Ingenio y construcción alegórica en dos arcos triunfales novohispanos". En Alicia Mayer (coord.), Carlos de Sigüenza y 
Góngora: homenaje 1700-2000. México: UNAM, Instituto de Investigaciones Históricas, 2000. 2 v. (Historia Novohispana; 65); vol. I, pp. 35-65.

MORALES FOLGUERA, José Miguel. "La fiesta barroca y el arte efímero en el virreinato de Nueva España”. Apotheca 6:2 (Córdoba, 1986): 9-25.

---- Cultura simbólica y arte efímero en la Nueva España. Sevilla: Junta de Andalucía, Consejería de Cultura y Medio Ambiente, 1991.

PARODI, Claudia. "El lenguaje de las fiestas: arcos triunfales y villancicos". En Judith Farré Vidal (ed.), Teatro y poder en la época de Carlos II: fiestas en torno a reyes y virreyes. Congreso celebrado en el Tecnológico de Monterrey, Monterrey, 23-25 de agosto de 2006. Pamplona: Universidad de Navarra; Madrid: Iberoamericana; Frankfurt am Main: Vervuert, 2007. (Biblioteca Indiana; 8); pp. 221-235.

PASCUAL BUXÓ, José (edición y prólogo.). Arco y certamen de la poesía mexicana colonial (siglo XVII). Xalapa, Veracruz: Universidad Veracruzana, 1959. (Cuadernos de la Facultad de Filosofía y Letras; 2).

---- "Palestras literarias, arcos triunfales (formas de poesía colonial)". Anuario de Filología 4 (Maracaibo, Venezuela, 1966): 217-246.

RAYA LEMUS, Zulema. "La imagen alegórica de la Nueva España y sus diferentes representaciones en el arte efímero novohispano". En Inmaculada Rodríguez Moya (ed.), Arte, poder e identidad en Iberoamérica: de los virreinatos a la construcción nacional. Castelló de la Plana: Universitat Jaume I, pp. 89-103.

RÍOS, Eduardo Enríque. "Carros triunfales en la jura real de Carlos III en México". En Retablo barroco a la memoria de Francisco de la Maza. México: UNAM, Instituto de Investigaciones Estéticas, 1974, pp. 297-299.

RODRÍGUEZ HERNÁNDEZ, Dalmacio. "Los arcos triunfales en la época de Carlos II: una aproximación desde la retórica". En Judith Farré Vidal (ed.), Teatro y poder en la época de Carlos II: fiestas en torno a reyes y virreyes. Congreso celebrado en el Tecnológico de Monterrey, Monterrey, 23-25 de agosto de 2006. Pamplona: Universidad de Navarra; Madrid: Iberoamericana; Frankfurt am Main: Vervuert, 2007. (Biblioteca Indiana; 8); pp. 267-285.

---- "Acerca de los genera dicendi en los arcos triunfales novohispanos en la época de los Austrias". En Judith Farré Vidal (ed.), Dramaturgia y espectáculo teatral en la época de los Austrias. Madrid: Iberoamericana; Frankfurt Am Main: Vervuert, 2009, pp. 217-232. 
ROJAS, Pedro. "Los arcos de triunfo y las portadas religiosas en la Nueva España”. Anales del Instituto de Investigaciones Estéticas 40 (México, UNAM, 1971): 15-20.

SEBASTIÁN LÓPEZ, Santiago. El barroco iberoamericano: mensaje iconográfico. Madrid: Ediciones Encuentro, 1990.

VELAZQUEZ CÁRDENAS Y LEON, Joaquín. Arcos de triunfo. Introducción por Roberto Moreno de los Arcos. México: UNAM, Instituto de Investigaciones Bibliográficas, 1978. (Boletín del Instituto de Investigaciones Bibliográficas. Suplemento; 5).

\subsection{Emblemática ${ }^{50}$}

CHIVA BELTRÁN, Juan. "La utilización del género emblemático en las entradas virreinales novohispanas y su proyección en el siglo XIX mexicano". En Rafael García Mahíques y Vicent Francesc Zuriaga Senent (eds.), Imagen y cultura: la interpretación de las imágenes como Historia cultural. Valencia: Generalitat Valenciana; Universitat Internacional de Gandía, 2008. 2 v. Vol. I, pp. 441-457.

GRAÑÉN PORRÚA, María Isabel. “Creaciones emblemáticas y alegorías en el México del Quinientos”. En Bárbara Skinfill Nogal y Eloy Gómez Bravo (eds.), Las dimensiones del arte emblemático. Zamora, Michoacán: El Colegio de Michoacán; Consejo Nacional de Ciencia y Tecnología, 2002, pp. 203-220.

HERNÁNDEZ REYES, Dalia. "Festín de las morenas criollas: danza y emblemática en el recibimiento del marqués de Villena (México, 1640). En Judith Farré Vidal (ed.), Dramaturgia y espectáculo teatral en la época de los Austrias. Madrid: Iberoamericana; Frankfurt am Main: Vervuert, 2009, pp. 339-358.

LÓPEZ POZA, Sagrario. "Los estudios sobre emblemática: logros, perspectivas y tendencias de investigación". SIGNO. Revista de Historia de la Cultura Escrita 6 (Alcalá de Henares, 1999): 81-95.

MÍNGUEZ, Víctor. "La emblemática novohispana”. En Bárbara Skinfill Nogal y Eloy Gómez Bravo (eds.), Las dimensiones del arte emblemático. Zamora, Michoacán: El Colegio de Michoacán; Consejo Nacional de Ciencia y Tecnología, 2002, pp. 139-166.

\footnotetext{
${ }^{50}$ Recojo únicamente los no incluidos en la revisión bibliográfica llevada a cabo por SKINFILL NOGAL, Bárbara, "Los caminos de la emblemática novohispana: una aproximación bibliográfica", en Bárbara Skinfill Nogal y Eloy Gómez Bravo (eds.), Las dimensiones del arte emblemático, Zamora, Michoacán: El Colegio de Michoacán; Consejo Nacional de Ciencia y Tecnología, 2002, pp. 45-72.
} 
MÍNGUEZ, Víctor; Inmaculada RODRÍGUEZ MOYA; Pablo GONZÁLEZ TORNEL y Juan CHIVA BELTRÁN. “Cultura emblemática y jeroglíficos festivos”. En Víctor Mínguez Cornelles et alii, La fiesta barroca: los virreinatos americanos (1560-1808). Castelló de la Plana: Universitat Jaume I; Las Palmas: Universidad de las Palmas de Gran Canaria, 2012. (Triunfos Barrocos; 2); pp. 105-121.

MORALES FOLGUERA, José Miguel. "La emblemática en el arte religioso de Iberoamérica". En Inmaculada Rodríguez y Víctor Mínguez (eds.), Arte en los confines del imperio: visiones hispánicas de otros mundos. Castelló: Universitat Jaume I, 2001, pp. 199-219.

PASCUAL BUXÓ, José. El resplandor intelectual de las imágenes: estudios de emblemática y literatura novohispana. México: UNAM, Coordinación de Humanidades, 2002.

VALBERT, Christian. La iconografía simbólica del arte barroco de Latinoamérica: teoría europea, práctica brasileña. La Paz, Bolivia: Amigos del Libro, 1987.

\subsection{Pirotecnia}

ALBERRO, Solange. "Los efectos especiales en las fiestas virreinales de Nueva España y Perú”. Historia Mexicana n 230, vol. 59:3 (México, enero-marzo 2010): 837875.

MARTÍNEZ MARÍN, Carlos. "La pirotecnia: de las 'bellas y exquisitas invenciones de fuego"'. En El arte efímero en el mundo hispánico. México: UNAM, Instituto de Investigaciones Estéticas, 1983. (Estudios de Arte y Estética; 17), pp. 201-227.

\subsection{Tedeum}

ORTEMBERG, Pablo. "El Tedeum en el ritual político: usos y sentidos de un dispositivo de pactos en la América española y en la Revolución de Mayo". Anuario del Instituto de Historia Argentina 10 (La Plata, Argentina, 2010): 199-226.

\subsection{Relaciones de sucesos}

MÍNGUEZ, Víctor; Inmaculada RODRÍGUEZ MOYA; Pablo GONZÁLEZ TORNEL y Juan CHIVA BELTRÁN. "El relato impreso de la fiesta hispanoamericana: libros y estampas". En Víctor Mínguez et alii, La fiesta barroca: los virreinatos americanos (15601808). Castelló de la Plana: Universitat Jaume I; Las Palmas: Universidad de las Palmas de Gran Canaria, 2012. (Triunfos Barrocos; 2), pp. 21-33. 
PENA SUEIRO, Nieves. "Estado de la cuestión sobre el estudio de las Relaciones de sucesos". Pliegos de Bibliofilia 13 (1 trimestre de 2001): 43-66.

SOLANO Y PÉREZ-LILA, Francisco de. "Fiestas en la ciudad de México". En La ville en l'Amérique espagnole coloniale. París: Université de la Sorbonne NouvelleParis III, 1984, pp. 243-332. Reeditado en F. de Solano, Ciudades hispanoamericanas y pueblos de indios. Madrid: CSIC, 1990. (Biblioteca de América; 2), pp. 247-309 ${ }^{51}$. Reelaborado en F. de Solano, Las voces de la ciudad: México a través de sus impresos (15391821). Madrid: CSIC, 1994. (Biblioteca de Historia de América; 9), pp. XLVII-LIV (estudio preliminar), 161-208 (siglos XVI-XVIII) y 248-254 (1808-1821).

\section{ESTUDIOS GENERALES}

\subsection{América general}

BAYLE, Constantino (S.J.). Los cabildos seculares en la América española. Madrid: Sapientia, $1952^{52}$.

BRISSET, Demetrio E. "Fiestas hispánicas en América". En Rafael Briones Gómez el alii, América: una reflexión antropológica. Granada: Diputación Provincial, 1992, pp. 43-52.

ESTEVA FÁBREGAT, Claudio. "Dramatización y ritual de la fiesta en Hispanoamérica”. En José María Díez Borque (ed.), Teatro y fiesta en el Barroco: España e Iberoamérica. Barcelona: Ediciones del Serbal, 1986, pp. 137-152.

FARRÉ VIDAL, Judith (ed.). Teatro y poder en la época de Carlos II: fiestas en torno a reyes y virreyes. Congreso celebrado en el Tecnológico de Monterrey, Monterrey, 23-25 de agosto de 2006. Pamplona: Universidad de Navarra; Madrid: Iberoamericana; Frankfurt am Main: Vervuert, 2007. (Biblioteca Indiana; 8).

GARCÍA VALDES, Celsa Carmen. "Fiesta y poder en los virreinatos americanos". En Memoria del IV Encuentro internacional sobre barroco: la fiesta (La Paz, Bolivia, 2007). Pamplona: Fundación Visión Cultural; Universidad de Navarra, 2011, pp. 253-259. Edición digital a partir de La Paz, Unión Latina, 2007, http://unav.es/publicacion/encuentros-barroco-bolivia/cuarto-encuentro (consultado el 1 de octubre de 2017).

51 Solano divide la fiesta, de la que ofrece relaciones desde el siglo XVI a 1821, en 1. Fiestas municipales o patronales. 2. Fiestas nacionales. 3. Festejos con motivo de la llegada de autoridades. 4. Fiestas de gremios, estamentos, asociaciones y corporaciones. 5. Túmulos, exequias, duelos.

${ }^{52}$ Las fiestas organizadas por los cabildos son analizadas en los capítulos XIII (paseo del pendón real), XIV (lutos, proclamaciones y juras, recibimiento del sello real), XV (entradas de virreyes), XVI (nacimiento de príncipes, canonizaciones, beatificaciones) y XVIII (Corpus y toros). 
GARRIDO ARANDA, Antonio (comp.). El mundo festivo en España y América. Córdoba: Universidad de Córdoba, 2005.

GISBERT, Teresa. "La fiesta en el tiempo". En Memoria del IV Encuentro internacional sobre barroco: la fiesta (La Paz, Bolivia, 2007). Pamplona: Fundación Visión Cultural; Universidad de Navarra, 2011, pp. 35-50.

LÓPEZ CANTOS, Ángel. Juegos, fiestas y diversiones en la América española. Madrid: Mapfre, 1992.

MÍNGUEZ CORNELLES, Víctor Manuel. "Los 'Reyes de las Américas': presencia y propaganda de la monarquía hispánica en el Nuevo Mundo". En Agustín González Enciso y Jesús María Usunáriz Garayoa (dirs.), Imagen del rey, imagen de los reinos: las ceremonias públicas en la España Moderna (1500-1814). Pamplona: EUNSA, 1999, pp. 231-257.

---- "Espectáculos imperiales en tierras de indios". En La fiesta en la Europa de Carlos V. Sevilla: Sociedad Estatal para la Conmemoración de los centenarios de Felipe II y Carlos V, 2000, pp. 235-255.

---- et alii. La fiesta barroca: los virreinatos americanos (1560-1808). Castelló de la Plana: Universitat Jaume I; Las Palmas: Universidad de las Palmas de Gran Canaria, 2012. (Triunfos Barrocos; 2).

\subsection{México}

BERNDT LEÓN MARISCAL, Beatriz. "Memoria pictórica de la fiesta barroca en la Nueva España”. En Jaime Cuadriello (dir.), Los pinceles de la Historia: De la patria criolla a la nación mexicana (1750-1860). México: Museo Nacional de Arte; UNAM, Instituto de Investigaciones Estéticas; Banamex, 2000, pp. 93-104.

BRAVO ARRIAGA, María Dolores. "La fiesta pública: su tiempo y espacio". En Antonio Rubial García (coord.), La ciudad barroca. México: FCE; Colegio de México, 2005. (Historia de la vida cotidiana en México; 2), pp. 435-460.

CÁRDENAS GUTIÉRREZ, Salvador. "Las insignias del rey: disciplina y ritual público en la ciudad de México (siglos XVI-XVIII)". Jabrbuch für Geschichte Lateinamerikas 39 (Colonia, 2002): 193-216.

FARRÉ VIDAL, Judith. Espacio y tiempo de fiesta en Nueva España (1665-1760). Madrid: Iberoamericana; Frankfurt Am Main: Vervuert, 2013. (Biblioteca Indiana; 35).

GONZALBO AIZPURU, Pilar. "Las fiestas novohispanas: espectáculo y ejemplo”. Mexican Studies/Estudios Mexicanos 9:1 (Berkeley, Ca., 1993): 19-45. 
HERNÁN RAMÍREZ, Hugo. Fiesta, espectáculo y teatralidad en el México de los conquistadores. Madrid: Iberoamericana; Frankfurt am Main: Vervuert, 2009. (Textos y estudios coloniales y de la independencia; 19).

MARTÍNEZ VILLA, Juana. La fiesta regia en Valladolid de Michoacán: politica, sociedad y cultura en el México borbónico. Tesis para obtener el título de Maestra en Historia. Morelia, Michoacán: Universidad Michoacana de San Nicolás de Hidalgo, febrero de 2006.

MÍNGUEZ CORNELLES, Víctor. Los reyes distantes: imágenes del poder en el México virreinal. Castelló de la Plana: Universitat Jaume I, 1991. (Biblioteca de les Aules; 2).

---- "Arte, espectáculo y poder en las fiestas novohispanas". En Herón Pérez Martínez (ed.), México en fiesta. Zamora, Michoacán: El Colegio de Michoacán; Gobierno del Estado, Secretaría de Turismo, 1998, pp. 315-327.

---- "La fiesta política virreinal: propaganda y aculturación en el México del siglo XVII”. En Karl Kohut y Sonia V. Rose (eds.), La formación de la cultura virreinal. II. El siglo XVII. Madrid: Iberoamericana; Frankfurt am Main: Vervuert: 2004, pp. 359374.

PÉREZ MARTÍNEZ, Herón (ed.). México en fiesta. Zamora, Michoacán: El Colegio de Michoacán; Gobierno del Estado, Secretaría de Turismo, 1998.

RAMOS SOSA, Rafael. "La fiesta barroca en Ciudad de México y Lima". Historia 30 (Santiago de Chile, 1997): 263-286.

RODRÍGUEZ HERNÁNDEZ, Dalmacio. Texto y fiesta en la literatura novohispana (1650-1700). Prefacio de José Pascual Buxó. México: UNAM, Instituto de Investigaciones Bibliográficas, 1998. (Estudios de cultura literaria novohispana; 13).

---- "La fiesta novohispana: cohesión social e identidad criolla". En Homenaje Carlos de Sigüenza y Góngora 1700-2000. México: Archivo General de la Nación, 2000, pp. 11-19.

---- "La imagen de Carlos II en la Nueva España: festejos reales en 1676". En José Pascual Buxó (ed.), La producción simbólica en la América colonial. México: UNAM, Instituto de Investigaciones Bibliográficas, 2001, pp. 173-191.

ROMERO DE TERREROS, Manuel. Torneos, mascaradas y fiestas reales en la Nueva España. México: Tip. Murguía, 1918. (Cultura, vol. 9, nº 4). 
RUBIAL GARCÍA, Antonio. "La ciudad y la fiesta". En A. Rubial García, La plaza, el palacio y el convento: la ciudad de México en el siglo XVII. México: Consejo Nacional para la Cultura y las Artes, 1998, pp. 50-63.

RUIZ MEDRANO, Carlos Rubén. Fiestas y procesiones en el mundo colonial novohispano: los conflictos de preeminencias y una sátira carnavalesca del siglo XVIII. San Luis Potosí, México: El Colegio de San Luis, 2001.

SOLANGE, Alberro. "Imagen y fiesta barroca: Nueva España, siglos XVIXVII". En Petra Schumm (ed.), Barrocos y modernos: nuevos caminos en la investigación del Barroco iberoamericano. Frankfurt am Main: Vervuert; Madrid: Iberoamericana, 1998, pp. 33-48.

TERÁN BONILLA, José Antonio. "La ciudad novohispana y la fiesta barroca". En Memoria del IV Encuentro internacional sobre barroco: la fiesta (La Paz, Bolivia, 2007). Pamplona: Fundación Visión Cultural; Universidad de Navarra, 2011, pp. 315-322. Edición digital a partir de La Paz, Unión Latina, 2007, http://unav.es/publicacion/encuentros-barroco-bolivia/cuarto-encuentro (consultado el 1 de octubre de 2017).

VÁSQUEZ MELÉNDEZ, Miguel Angel. Fiesta y teatro en la ciudad de México (1750-1910): dos ensayos. México D.F.: Consejo Nacional para la Cultura y las Artes; Instituto Nacional de Bellas Artes; Centro Nacional de Investigación, Documentación e Información Teatral "Rodolfo Usigli", $2003^{53}$.

VIQUEIRA ALBÁN, Juan Pedro. ¿Relajados o reprimidos?: Diversiones públicas y vida social en la ciudad de México durante el Siglo de las Luces. México: FCE, 1987.

\subsection{Perú}

ACOSTA DE ARIAS SCHREIBER, Rosa María. Fiestas coloniales urbanas (LimaCurco-Potosí). Lima: Otorongo, 1997.

BROMLEY, Juan. "Fiestas caballerescas, populares y religiosas en la Lima virreinal” Revista Histórica 27 (Lima, 1964): 200-220.

ESTABRIDIS CÁRDENAS, Ricardo. "Iconografía del poder en el Reino del Perú de 1750 al epílogo colonial: el retrato y la fiesta". En Inmaculada Rodríguez Moya

${ }^{53}$ I. "Los espacios recreativos dentro de la reforma urbana de la ciudad de México durante la segunda mitad del siglo XVIII", pp. 11-268. II. "Teatro y calendario cívico en la ciudad de México, 1824-1910: un medio para el fomento del teatro”, pp. 269-346. 
(ed.), Arte, poder e identidad en Iberoamérica: de los virreinatos a la construcción nacional. Castelló de la Plana: Universitat Jaume I, 2008, pp. 117-144.

GARCÍA MORALES, Alfonso. "Las fiestas de Lima (1632) de Rodrigo de Carvajal y Robles”. Anuario de Estudios Americanos 44 (Sevilla, 1987): 141-171.

GISBERT, Teresa. "La fiesta y la alegoría en el virreinato peruano". En El arte efímero en el mundo hispánico. México: UNAM, Instituto de Investigaciones Estéticas, 1983, pp. 145-181.

IWASAKI CAUTI, Fernando. "Toros y sociedad en Lima colonial". Anuario de Estudios Americanos 49 (Sevilla, 1992): 311-333.

PÉRISSAT, Karine. "Arrivées de vice-rois et événements royaux célebrés au Callao à l'époque coloniale”. Caravelle 69 (Toulouse, 1997): 203-212.

---- "Les festivités dynastiques à Lima: la célébration d'une histoire locale". Caravelle 73 (Toulouse, 1999): 71-93.

---- 'L'Amérique mise à l'honneur: l'exaltation du Pèrou dans las fêtes royales à Lima (XVIIe et XVIIIe siècles)". Monographie de la Revue du CRAEC 2 (Paris III, Université de la Sorbonne Nouvelle, 2000). (Travaux et documents; 2).

---- "Le roi de la fête: représentation du povoir et de la personne royale dans les programmes festifs liméniens (XVIIe et XVIII siècles)". Histoire et Sociétés de l'Amérique Latine 11 (Paris, Revue de l'Association Aleph, 2000-1): 57-84.

---- "Las representaciones del espacio americano en las fiestas limeñas de la época colonial”. Criticón 78 (Toulouse, 2000): 29-43.

---- Lima fête ses rois (XVIe-XVIIIe siècles): hispanité et américanité dans las cérémonies royales. París: L'Harmattan, 2002.

RAMOS SOSA, Rafael. Arte festivo en Lima virreinal, siglos XVI-XVII. Sevilla: Junta de Andalucía, Consejería de Cultura y Medio Ambiente, 1992.

---- "La fiesta barroca en Ciudad de México y Lima". Historia 30 (Santiago de Chile, 1997): 263-286.

\subsection{Otros territorios}

ALFONSO MOLA, Marina y Carlos MARTÍNEZ SHAW. "Fiestas reales y toros en el Quito del siglo XVIII". En Antonio García-Baquero y Pedro Romero de 
Solís (eds.), Fiestas de toros y sociedad. Actas del Congreso Internacional celebrado en Sevilla del 26 de noviembre al 1 de diciembre de 2001. Sevilla: Real Maestranza de Caballería; Universidad de Sevilla; Fundación de Estudios Taurinos, 2003. (Tauromaquias; 5), pp. 123-138.

CAJÍAS DE LA VEGA, Fernando. "Fiestas barrocas en Charcas". En Memoria del IV Encuentro internacional sobre barroco: la fiesta (La Paz, Bolivia, 2007). Pamplona: Fundación Visión Cultural; Universidad de Navarra, 2011, pp. 51-67. Edición digital a partir de La Paz, Unión Latina, 2007, http:// unav.es/publicacion/encuentros-barrocobolivia/cuarto-encuentro (consultado el 1 de octubre de 2017).

CRUZ DE AMENÁBAR, Isabel. La fiesta: metamorfosis de lo cotidiano. Santiago de Chile: Universidad Católica de Chile, 1995. (Serie Arte y Sociedad en Chile 16501820).

---- "Arte festivo barroco: un legado duradero". Laboratorio de Arte 10 (Sevilla, 1997): 211-231.

---- "La fiesta religiosa en el reino de Chile: vivencia de un tiempo sagrado". Iter 6 (Santiago de Chile, 1998): 123-150. Número dedicado a "La fiesta como tiempo de Dios".

CRUZ ZÚÑIGA, Pilar. "La fiesta barroca en Quito: elementos simbólicos, poder y diferenciación social en las celebraciones efectuadas en 1766". En Actas del III Congreso Internacional del Barroco Americano: Territorio, Arte, Espacio y Sociedad. (Sevilla, 2001). Sevilla: Universidad Pablo de Olavide, Departamento de Humanidades, Area de Historia del Arte, 2001. CD-ROM, pp. 1243-1259. También en en Procesos: Revista Ecuatoriana de Historia 17 (Quito, 2001): 35-60.

JIMÉNEZ MENESES, Orián y Juan David MONTOYA GUZMÁN. "Fiesta y vida cotidiana en el Nuevo Reino de Granada, 1573-1810”. En Orián Jiménez Meneses y Juan David Montoya Guzmán (eds.), Fiesta, memoria y nación: ritos, símbolos y discursos, 1573-1830. Bogotá: Universidad Nacional de Colombia, 2011, pp. 23-64.

KENNEDY TROYA, Alexandra. "La fiesta barroca en Quito". Anales del Museo de América 4 (Madrid, 1996): 137-152. También en Procesos: Revista Ecuatoriana de Historia 9 (Quito, 1996): 3-20.

POLANCO GIRALDO, María Ximena. Fiestas y diversiones en Cartagena de Indias, 1740-1810. Tesis de maestría en Historia. Bogotá: Universidad Nacional de Colombia, Facultad de Ciencias Humanas, 1996. 
---- "Fiestas políticas en Cartagena de Indias, 1740-1810". En Marcos González Pérez (autor-comp.), Fiesta y región en Colombia. Bogotá: Cooperativa Editorial Magisterio, 1998, pp. 51-70.

RODRIGUEZ MOYA, Inmaculada y Víctor MINGUEZ CORNELLES. "Cultura simbólica y fiestas borbónicas en Nueva Granada: de las exequias de Luis I (1724) a la proclamación de Fernando VII (1808)". Revista CS en Ciencias Sociales 9 (Cali, Colombia): 115-143.

SALVADOR, José María. Efimeras efemérides: fiestas civicas y arte efímero en la Venezuela de los siglos XVII-XIX. Caracas: Universidad Católica Andrés Bello, 2001.

SOLANO Y PÉREZ-LILA, Francisco de. "Nivel cultural, teatro y diversiones colectivas en las ciudades de la Venezuela colonial (1747-1760)". Boletín de la Academia Nacional de la Historia, tomo LIX, no 233 (Caracas, 1976): 83-102. Reeditado bajo el título de "Diversiones colectivas en las ciudades de la Venezuela colonial (1747-1760)" en F. de Solano, Ciudades hispanoamericanas y pueblos de indios. Madrid: CSIC, 1990. (Biblioteca de América; 2), pp. 311-332.

VALENZUELA MÁRQUEZ, Jaime. "De las liturgias del poder al poder de las liturgias: para una antropología política del Chile colonial". Historia 32 (Lima, 1999): $575-675$.

---- Las liturgias del poder: celebraciones públicas y estrategias persuasivas en Chile colonial (1609-1709). Santiago de Chile: Centro de Investigaciones Diego Barros Arana; DIBAM; Lom Editores 2001. (Sociedad y Cultura; 27).

ZAPICO, Hilda Raquel. "Liturgia política, poder e imaginario en el Buenos Aires del siglo XVII: las fiestas reales". En Hilda Raquel Zapico (coord.), De prácticas, comportamientos y formas de representación social en Buenos Aires (s. XVII-XIX). Bahía Blanca, Buenos Aires: Universidad Nacional del Sur, 2006, pp. 97-166.

\section{CELEBRACIONES DINÁSTICAS}

\subsection{Natalicios}

\subsubsection{México}

FARRÉ VIDAL, Judith. "Los festejos por el nacimiento de Carlos II en la Nueva España: una máscara jocosa en Antequera (1662)”. En Anthony J. Close y Sandra María Fernández Vales (coords.), Edad de Oro Cantabrigense. Actas del VII Congreso de la Asociación Internacional Siglo de Oro (2005). Asociación Internacional Siglo de Oro, 2006, pp. 233-238. 
---- "Pasatiempos festivos en torno al nacimiento de Carlos II (Antequera, 1661)". En Lilian von der Walde Moheno et alii (eds.), "Injerto peregrino de bienes y grandezas admirables": Estudios de literatura y cultura española e hispanoamericana (siglos XVI al XVIII). México: Universidad Autónoma Metropolitana, Unidad Iztapalapa, División de Ciencias Sociales y Humanidades, 2007, pp. 717-728.

\subsubsection{Perú}

ROSE, Sonia V. "Tauromachie et esprit créole: les fêtes pour la naissance de Baltasar Carlos à Lima”. En Annie Molinié-Bertrand; Araceli Guillaume-Alonso et Jean-Paul Duviols, Tauromachie et société dans le monde ibérique et ibéro-américaine. Actes du Colloque International. París: Presses de l'Université de Paris-Sorbonne, 1999, pp. 151-163.

---- "Un grupo en busca de afirmación: las fiestas de los mulatos de Lima por el nacimiento del príncipe Baltasar Carlos”. En Karl Kohut y Sonia V. Rose (eds.), La formación de la cultura virreinal. II: El siglo XVII. Madrid: Iberoamericana; Frankfurt am Main: Vervuet, 2004, pp. 375-405.

\subsubsection{Otros territorios}

NAVARRO GARCÍA, Luis. "Fiesta en Bogotá en 1708 por el nacimiento del príncipe de Asturias". Historia Socialy Económica de América 2 (Alcalá de Henares, Madrid, 1986): 199-216.

RAMOS GÓMEZ, Luis y Carmen RUIGÓMEZ GÓMEZ. "El cabildo de Quito festeja el nacimiento de Luis I en 1708: tensiones con el comercio por su participación en las fiestas". En Manuela Cristina García Bernal y Sandra Olivero Guidobono (coords.), El municipio indiano: relaciones interétnicas, económicas y sociales. Homenaje a Luis Navarro García. Sevilla: Universidad de Sevilla, 2009, pp. 517-529.

\subsection{Bodas}

\subsubsection{América general}

GONZÁLEZ CRUZ, David. "Las bodas de la realeza y sus celebraciones festivas en España y América durante el siglo XVIII". Espacio, Tiempo y Forma, Serie IV, Historia Moderna, 10 (Madrid, 1997): 227-261.

--- "Nacidos para reinar: el ceremonial de la procreación en España y América durante el siglo XVIII". En David González Cruz (ed.), Ritos y ceremonias en el mundo hispano durante la Edad Moderna. Huelva: Universidad de Huelva, 2002, pp. 91-119. 


\subsection{Juras y proclamaciones reales}

\subsubsection{América general}

ALFONSO MOLA, Marina. "Fiestas en honor de un rey lejano: la proclamación de Felipe V en América". En Antonio de Béthencourt Massieu (coord.), Felipe $V$ y el Atlántico. III Centenario del advenimiento de los Borbones. Coloquio de Historia Canario-Americana (14 . 2000. Las Palmas de Gran Canaria). Las Palmas de Gran Canaria: Cabildo de Gran Canaria, 2002, pp. 249-308.

CALVO, Thomas. "Proclamations royales et indiens au XVIII siècle: enjeux politiques et sociaux". Anuario de Estudios Americanos 68:1 (Sevilla, 2011): 73-103.

\subsubsection{México}

CÁRDENAS GUTIÉRREZ, Salvador. "De las juras reales al juramento constitucional: tradición e innovación en el ceremonial novohispano, 1812-1820”. En La supervivencia del derecho español en Hispanoamérica durante la época independiente. Jornadas de Historia del Derecho $\left(2^{\circ}, 1998\right)$. México: UNAM, Instituto de Investigaciones Jurídicas, 1998, pp. 63-93.

CUADRIELLO, Jaime. "El discurso de la ceremonia de jura: un estatuto visual para el reino de Nueva España: el caso del Patronato Guadalupano de 1746". Tiempos de América 2 (Castellón de la Plana, 1998): 3-18.

ESCOLAR OLMEDO, Armando Mauricio. “Las fiestas de Pátzcuaro de 1701 por la aclamación del rey Felipe V". Tzintzun, Revista de Estudios Históricos, 9 (Morelia, Michoacán, 1988): 139-166.

GAYOL, Víctor. "El retrato del escondido: notas sobre un retrato de jura de Fernando VII en Guadalajara”. Relaciones. Estudios de Historia Social, vol. XXI, no 83 (Zamora, Michoacán, verano 2000): 151-181.

MÍNGUEZ CORNELLES, Víctor Manuel. "El rey sanador: meteorología y medicina en los jeroglíficos de la jura de Fernando VI". En Juegos de ingenio y agudera: la pintura emblemática de la Nueva España. Catálogo de la exposición celebrada en México D.F. (Museo Nacional de Arte), noviembre 1994-febrero 1995. México: Museo Nacional de Arte, 1994, pp. 182-191.

---- "Reyes absolutos y ciudades leales: las proclamaciones de Fernando VI en la Nueva España”. Tiempos de América 2 (Castellón de la Plana, 1998): 19-34. 
---- "Fernando VII: un rey imaginado para una nación inventada". En Jaime E. Rodríguez O. (coord.), Revolución, independencia y las nuevas naciones de América. Madrid: Fundación Mapfre Tavera, 2005, pp. 193-213.

---- "La ceremonia de jura en la Nueva España: proclamaciones fernandinas de 1747 y 1808 ". Varia Historia, vol. XXIII, n 38 (Belo Horizonte, Universidade Federal de Minas Gerais, 2007): 273-292.

OLMEDO GONZÁLEZ, José de Jesús. "La jura de Fernando VI: una visión compartida”. En Inmaculada Rodríguez Moya (ed.), Arte, poder e identidad en Iberoamérica: de los virreinatos a la construcción nacional. Castelló de la Plana: Universitat Jaume I, 2008, pp. 77-88.

RÍOS, Eduardo Enríque. "Carros triunfales en la jura real de Carlos III en México". En Retablo barroco a la memoria de Francisco de la Maza. México: UNAM, Instituto de Investigaciones Estéticas, 1974, pp. 297-299.

TOVAR DE TERESA, Guillermo. "Arquitectura efímera y fiestas reales: la jura de Carlos IV en la Ciudad de México, 1789". Artes de México, nueva época, 1 (México, 1988): 42-55. También en Boletín del Museo e Instituto "Camón Ažnar" 48-49 (Zaragoza, 1992): 353-378.

\subsubsection{Perú}

PANIAGUA PÉREZ, Jesús. "La loa en las Indias: la obra de Antonio Marcos en las fiestas de la coronación de Carlos IV en Cuenca del Perú". Estudios Humanísticos. Filología 19 (León, 1997): 91-106.

\subsubsection{Otros territorios}

BORGES Y JACINTO DEL CASTILLO, Analola. "Fiesta en Caracas (octubre 1701)". Revista de Historia 11 (Caracas, abril 1962): 13-26.

BRENES TENCIO, Guillermo. "Lealtad y fidelidad: la proclamación del rey Fernando VII en Cartago, provincia de Costa Rica, 1809”. Fronteras de la Historia 14-1 (Bogotá, Instituto Colombiano de Antropología e Historia, 2009): 66-97.

CÁRDENAS SIRVÁN, Inmaculada. "Los festejos en la provincia de Mojos, con motivo de la coronación de Carlos IV". Anuario de Estudios Americanos 34 (Sevilla, 1977): 759-773. 
CALVO, Thomas. "La jura de Fernando VI en Guadalajara (1747): de la religión real a la festividad”. Takwá: Revista de Historia 8 (Guadalajara, Jalisco, 2005): 67-92.

CHAUCA GARCÍA, Jorge. "Fiesta real y lealtad americana: la proclamación de Carlos IV en San Felipe de Lerma (Salta).” En Francisco Núñez Roldán (coord.), Ocio y vida cotidiana en el mundo hispánico en la Edad Moderna. Sevilla: Universidad de Sevilla, 2007. (Historia y Geografía; 120), pp. 557-568.

FAJARDO DE RUEDA, Marta. "La jura del rey Carlos IV en la Nueva Granada". Anales del Instituto de Investigaciones Estéticas, vol. XXII, n ${ }^{\circ} 74-75$ (México, 1999): 195-209.

GONZÁLEZ PÉREZ, Marcos. "Juras borbónicas en Santa Fe de Bogotá". Memoria 2 (Bogotá, Archivo General de la Nación, 1997): 54-81.

PAGE, Carlos A. "Las proclamaciones reales en Córdoba de Tucumán". Revista Complutense de Historia de América 30 (Madrid, 2004): 77-94.

SALAZAR BRAVO, Rosario. "La jura de Carlos IV: un escenario barroco para la Caracas del siglo XVIII". En Memoria del IV Encuentro internacional sobre barroco: la fiesta (La Paz, Bolivia, 2007). Pamplona: Fundación Visión Cultural; Universidad de Navarra, 2011, pp. 323-330. Edición digital a partir de La Paz, Unión Latina, 2007, http://unav.es/publicacion/encuentros-barroco-bolivia/cuarto-encuentro (consultado el 1 de octubre de 2017).

VALENZUELA MÁRQUEZ, Jaime. "Poder y pirotecnia, artesanos y mapuches: apogeo barroco de las proclamaciones reales en Santiago de Chile, 1760-1789". Colonial Latin American Historical Review 14:1 (Alburquerque, N.M., 2005): 49-78.

VELASCO PEDRAZA, Julián Andrei. "La jura de Carlos III en la villa de San Gil: un aporte documental". Anuario de Historia Regional y de las Fronteras 13:1 (Bucaramanga, Colombia, 2008).

---- "Celebrar el poder: juras y proclamaciones en el Nuevo Reino de Granada, 1747-1812”. En Orián Jiménez Meneses y Juan David Montoya Guzmán (eds.), Fiesta, memoria y nación: ritos, simbolos y discursos, 1573-1830. Bogotá: Universidad Nacional de Colombia, 2011, pp. 107-129.

---- "Fiesta y poder: persistencias y significaciones de las representaciones sobre el poder en la ciudad de Panamá a través de las juras, 1747-1812". Boletín de la Asociación para el Fomento de los Estudios Históricos en Centroamérica 48 (enero-marzo, 2011), http://afehc-historia- centroamericana;org/index.php?action=fi_aff\&amp;id=2593 (consultado el 1 de octubre de 2017). 


\subsection{Cumpleaños}

\subsubsection{México.}

RIVERA, Octavio. "Fiestas en México por el cumpleaños de Carlos II y la Descripción poética de la máscara y fiestas... de Alonso Ramírez de Vargas, México 1670". En Judith Farré Vidal (ed.), Teatro y poder en la época de Carlos II: fiestas en torno a reyes y virreyes. Congreso celebrado en el Tecnológico de Monterrey, Monterrey, 23-25 de agosto de 2006. Pamplona: Universidad de Navarra; Madrid: Iberoamericana; Frankfurt am Main: Vervuert, 2007. (Biblioteca Indiana; 8); pp. 257-266.

\subsection{Exequias y honras fúnebres}

\subsubsection{Estudios generales}

ALLO MANERO, María Adelaida. "Iconografía funeraria de las honras de Felipe IV en España e Hispanoamérica". Cuadernos de Investigación. Historia 7: 1-2 (Logroño, Universidad de la Rioja, 1981): 73-96.

---- "Aportación al estudio de las exequias reales en Hispanoamérica: la influencia sevillana en algunos túmulos limeños y mejicanos". Anuario del Departamento de Historia y Teoría del Arte 1 (Madrid, 1989): 121-137.

---- Exequias reales de la Casa de Austria en España, Italia e Hispanoamérica. Zaragoza: Universidad de Zaragoza, 1993. (Tesis Doctoral. Edición en microfichas).

---- "Las exequias reales de la Casa de Austria en España, Italia e Hispanoamérica". Artigrama: Revista del Departamento de Historia del Arte de la Universidad de Zaragoza 10 (Zaragoza, 1993): 597-602.

---- "Las exequias reales de la Casa de Austria y el arte efímero español: estado de la cuestión”. En Bernardo José García García y María Luisa Lobato López (coords.), La fiesta cortesana en la época de los Austrias. Valladolid: Junta de Castilla y León, 2003, pp. $117-135$.

MEJÍAS ÁLVAREZ, María Jesús. Fiesta y muerte regia: las estampas de túmulos reales del AGI. Sevilla: CSIC, Escuela de Estudios Hispanoamericanos, 2002. (Difusión y Estudio).

---- "Pyras Philípicas: los túmulos de Felipe III y Felipe IV en la ciudad de Ecija”. Laboratorio de Arte 18 (Sevilla, 2005): 193-200. 
MORALES FOLGUERA, José Miguel. "Los túmulos funerarios de Carlos III y la imagen del rey en Hispanoamérica y Filipinas". Boletin de Arte 9 (Málaga, Universidad de Málaga, 1988): 135-158.

RAMOS SOSA, Rafael. "Los túmulos de Carlos III en Hispanoamérica: México, Lima, Santiago de Chile y Valparaíso". Cuadernos de Arte Colonial 6 (Madrid, Museo de América, 1990): 33-53.

VARELA, Javier. La muerte del rey: el ceremonial funerario de la monarquía española (1500-1885). Madrid: Turner, 1990.

\subsubsection{México}

BRAVO ARRIAGA, María Dolores. "El otro rostro de Jano: rituales y celebraciones fúnebres en honor del 'más Claro Sol de las Españas': Felipe IV, 1666". En Herón Pérez Martínez (ed.), México en fiesta. Zamora, Michoacán: El Colegio de Michoacán; Gobierno del Estado, Secretaría de Turismo, 1998, pp. 329-337.

CÁRDENAS GUTIÉRREZ, Salvador. “A rey muerto, rey puesto: imágenes del derecho y del Estado en las exequias reales de la Nueva España (1558-1700)”. En Bárbara Skinfill Nogal y Eloy Gómez Bravo (eds.), Las dimensiones del arte emblemático. Zamora, Michoacán: El Colegio de Michoacán; Consejo Nacional de Ciencia y Tecnología, 2002, pp. 167-195.

CHOCANO MENA, Magdalena. "Poder y trascendencia: la muerte del rey desde la perspectiva novohispana (s. XVI y XVII)". Jahrbuch für Geschichte Lateinamerikas 36 (Colonia, 1999): 83-104.

CUESTA HERNÁNDEZ, Luis Javier. "México insigne honras celebró a su rey: algunas precisiones sobre el ceremonial fúnebre de la dinastía de los Austrias en la Nueva España". Via Spiritus: Revista de História da Espiritualidade e do Sentimento Religioso 15 (Oporto, 1996): 83-106.

---- "La otra fiesta: las exequias de los Austrias en el virreinato de la Nueva España”. En Memoria del IV Encuentro internacional sobre Barroco: la fiesta (La Paz, Bolivia, 2007). Pamplona: Fundación Visión Cultural; Universidad de Navarra, 2011, pp. 87-100. Edición digital a partir de La Paz, Unión Latina, 2007, http://unav.es/publicacion/encuentros-barroco-bolivia/cuarto-encuentro (consultado el 1 de octubre de 2017).

FUENTE, Beatriz de la (coord.); Louise NOELLE (ed.). Arte funerario. Coloquio internacional de Historia del Arte (México, 1980). México: UNAM, Instituto de Investigaciones Históricas, 1987. 2 v. (Cuadernos de Historia del Arte; 41). 
GONZÁLEZ ACOSTA, Alejandro. "Un insólito túmulo del barroco popular novohispano: el de Carlos II (Coatepec, Puebla, 1701)". En Antonio Pablo Bernat Vistarini y John T. Cull (eds.), Los días de Alción: emblemas, literatura y arte del Siglo de Oro. Palma de Mallorca: José J. Olañeta, editor, 2002, pp. 295-302.

MARISCAL, Beatriz. "La muerte de una reina lejana: las exequias de Mariana de Austria en la Nueva España”. En Judith Farré Vidal (ed.), Teatro y poder en la época de Carlos II: fiestas en torno a reyes y virreyes. Congreso celebrado en el Tecnológico de Monterrey, Monterrey, 23-25 de agosto de 2006. Pamplona: Universidad de Navarra; Madrid: Iberoamericana; Frankfurt am Main: Vervuert, 2007. (Biblioteca Indiana; 8); pp. 187-197.

MARTÍNEZ ROSALES, Alfonso. "Reales exequias en San Luis Potosí". En Juegos de ingenio y agudeza: la pintura emblemática de la Nueva España. Catálogo de la exposición celebrada en México D.F. (Museo Nacional de Arte), noviembre 1994febrero 1995. México: Museo Nacional de Arte, 1994, pp. 170-180.

MAZA, Francisco de la. Las piras funerarias en la historia y en el arte de México: grabados, litografías y documentos del siglo XVI al XIX. México: UNAM, Instituto de Investigaciones Estéticas, 1946.

MÍNGUEZ CORNELLES, Víctor. "La muerte del príncipe: reales exequias de los últimos Austrias en México". Cuadernos de Arte Colonial 6 (Madrid, Museo de América, 1990): 5-32.

---- "Túmulo de Carlos V en la ciudad de México". En Joaquín Berchez (coord.), Los siglos de oro en los virreinatos de América, 1500-1700. Madrid: Sociedad Estatal para la Conmemoración de los centenarios de Felipe II y Carlos V, 1999, pp. 253-255.

---- "Imperio y muerte: las exequias de Carlos II y el fin de la dinastía en ambas orillas del Atlántico". En Inmaculada Rodríguez Moya (ed.), Arte, poder e identidad en Iberoamérica: de los virreinatos a la construcción nacional. Castelló de la Plana: Universitat Jaume I, 2008, pp. 17-51.

MÍNGUEZ, Víctor; Inmaculada RODRÍGUEZ MOYA; Pablo GONZÁLEZ TORNEL y Juan CHIVA BELTRÁN. "La muerte en el virreinato de la Nueva España: túmulos, piras y catafalcos". En Víctor Mínguez Cornelles et alii, La fiesta barroca: los virreinatos americanos (1560-1808). Castelló de la Plana: Universitat Jaume I; Las Palmas: Universidad de las Palmas de Gran Canaria, 2012. (Triunfos Barrocos; 2), pp. 55-69.

MORALES FOLGUERA, José Miguel. "Los programas iconográficos en el arte funerario mexicano". Cuadernos de Arte e Iconografía 2:4 (Madrid, Fundación Universitaria Española, 1989): 43-53. 
---- "El túmulo de Felipe IV en la catedral de México". Boletín de Arte 11 (Málaga, Universidad de Málaga, 1990): 105-118.

---- "Iconografía solar del túmulo de Carlos II en la catedral de México". Boletín de Bellas Artes 18 (Sevilla, Real Academia de Bellas Artes de Santa Isabel de Hungría, 1990): 233-240.

---- Cultura simbólica y arte efímero en la Nueva España. Sevilla: Junta de Andalucía, Consejería de Cultura y Medio Ambiente, 1991. Especialmente el "Estudio iconográfico y arquitectónico de los principales túmulos novohispanos”, pp. 189-285.

NOVO VALENCIA, Gerardo. El túmulo o catafalco colonial de Toluca y su posible dedicación. Toluca, Estado de México: Ayuntamiento de Toluca, 2000.

RODRÍGUEZ ÁLVAREZ, María de los Ángeles. Usos y costumbres funerarias en la Nueva España. Zamora, Michoacán: El Colegio de Michoacán; El Colegio Mixquense, $2001^{54}$.

SEBASTIÁN LÓPEZ, Santiago. "El programa simbólico del túmulo de Carlos V en México". En Donald Robertson et alii, Del arte: homenaje a Justino Fernánder: México: UNAM, Instituto de Investigaciones Estéticas, 1977, pp. 55-63.

---- "Los catafalcos en Hispanoamérica". En S. Sebastián, Contrarreforma y Barroco. Madrid: Alianza Editorial, 1981. (Alianza Forma; 21), pp. 110-115.

---- "Los jeroglíficos del catafalco mexicano de Fernando VI". En Arte funerario. México: UNAM, Instituto de Investigaciones Estéticas, 1987. (Cuadernos del Historia del Arte; 41-I), pp. 213-236.

---- "Arte funerario y astrología: la pira de Luis I". Ars Longa: Cuadernos de Arte 2 (Valencia, 1991): 113-126.

VARGAS LUGO, Elisa. "Dos piras funerarias barrocas". Anales del Instituto de Investigaciones Estéticas, vol. XIV, no 53 (México, 1983): 49-63.

\subsubsection{Perú}

CAMPOS Y FERNÁNDEZ DE SEVILLA, Francisco Javier. "Exequias en honor de Felipe III celebradas en Lima en 1621". Hispania Sacra, vol. LIII, no 107 (Madrid, 2001): 327-344.

\footnotetext{
${ }^{54}$ Especialmente el capítulo VII (“La muerte privilegiada”), donde se describe el túmulo funerario de Toluca, que aunque arte efímero ha llegado a nuestros días, y las exequias reales.
} 
ESTABRIDIS CÁRDENAS, Ricardo. "Los grabados de túmulos efímeros en Lima colonial". Letras, año 69, no 95-96 (Lima, 1998): 33-66.

MEJÍAS ÁLVAREZ, María Jesús. "Muerte regia en cuatro ciudades peruanas del barroco". Anuario de Estudios Americanos 69 (Sevilla, 1993): 189-205.

MÍNGUEZ, Víctor. "El fénix y la perpetuación de la realeza: el catafalco de Carlos II en la catedral de Lima en 1701". Millars. Espai i Història, 14 (Castellón de la Plana, 1991): 139-152.

MÍNGUEZ, Víctor; Inmaculada RODRÍGUEZ MOYA; Pablo GONZÁLEZ TORNEL y Juan CHIVA BELTRÁN. "Mausoleos efímeros en el virreinato del Perú". En Víctor Mínguez Cornelles et alii, La fiesta barroca: los virreinatos americanos (1560-1808). Castelló de la Plana: Universitat Jaume I; Las Palmas: Universidad de las Palmas de Gran Canaria, 2012. (Triunfos Barrocos; 2); pp. 71-83.

POUNCEY, Lorene. "Túmulos of Colonial Peru". The Art Bulletin 67 (New York, 1985): 18-32.

---- "Grabados de túmulos peruanos". Documentos de Arquitectura Nacional y Americana (DANA) 28/29 (Resistencia, Instituto Argentino de Investigaciones de la Arquitectura y del Urbanismo, 1989-1990): 82-95.

RAMOS SOSA, Rafael. Arte festivo en Lima virreinal, siglos XVI-XVII. Sevilla: Junta de Andalucía, Consejería de Cultura y Medio Ambiente, 1992; especialmente el capítulo III, "La fiesta luctuosa".

ROSE, Sonia V. "El primer rey que te falta: honras fúnebres a Carlos V en la Ciudad de los Reyes". En Annie Molinié-Bertrand et Jean-Paul Duviols, Charles Quint et la monarchie universelle. París: Presses de l'Université de Paris-Sorbonne, 2001, pp. 215238.

---- "La hija pródiga del imperio: honras fúnebres a Carlos V en la Ciudad de los Reyes". En Eduardo Hopkins Rodríguez (ed.), Homenaje a Luis Jaime Cisneros. Lima: Pontificia Universidad Católica del Perú, 2002; vol. II, pp. 1401-1421. También en Destiempos, año III, $\mathrm{n}^{\circ} 14$ (México, D.F., marzo-abril 2008): 129-141, http:// destiempos.com/n14/rose.pdf (consultado el 1 de octubre de 2017).

RUIZ DE PARDO, Carmen. "La muerte privilegiada: reales exequias en Lima y Cuzco. Epoca borbónica". En Inmaculada Rodríguez Moya (ed.), Arte, poder e identidad en Iberoamérica: de los virreinatos a la construcción nacional. Castelló de la Plana: Universitat Jaume I, 2008, pp. 53-76. 
TORRE REVELLO, José. "La crónica de las exequias de Carlos V en la Ciudad de los Reyes, año 1559". Boletín del Instituto de Investigaciones Históricas, año XIV, $n^{\circ}$ 51-52 (Buenos Aires, 1932): 60-78.

VIFORCOS MARINAS, María Isabel. "Fray Fernando de Valverde, O.S.A., y las exequias de Felipe III en Lima”. Archivo Agustiniano, vol. LXXVIII, n 196 (Valladolid, 1994): 249-278.

\subsubsection{Otros territorios}

BERLIN, Heinrich y Jorge LUJÁN MUÑOZ. Los túmulos funerarios en Guatemala. Guatemala: Academia de Geografía e Historia, 1983.

CAMPOS Y FERNÁNDEZ DE SEVILLA, Francisco Javier. "Primera fiesta barroca celebrada en Quito: funerales en la iglesia de San Agustín por la reina $\mathrm{D}^{\mathrm{a}}$ Isabel de Borbón en 1645”. Archivo Agustiniano, vol. 84, n 202 (Valladolid, 2000): 3-31.

CHAUCA GARCÍA, Jorge. "Exequias celebradas en el reino de Chile por Carlos III”. Espacio, Tiempo y Forma, Serie IV, Historia Moderna, 17 (Madrid, 2004): 255-272.

DAIRON, Émilie. "La primera flor de lis en los Andes: las exequias de Luis I en Santa Fe de Bogotá". En Karl Kohut y Sonia V. Rose (eds.), La formación de la cultura virreinal. III: El siglo XV III. Madrid: Iberoamericana; Frankfurt am Main: Vervuet, 2006, pp. 185-203.

\section{LAS ENTRADAS DEL ALTER EGO DEL REY AUSENTE}

\subsection{América general}

CASADO TRIGO, Manuel. "Aproximación al ceremonial y protocolo en los virreinatos americanos: el recibimiento virreinal". Revista de Derecho UNED (RDUNED), 11 (Madrid, 2012): 125-135. doi: 10.5944/rduned.11.2012.11127.

MÍNGUEZ, Víctor; Inmaculada RODRÍGUEZ MOYA; Pablo GONZÁLEZ TORNEL y Juan CHIVA BELTRÁN. "Triunfos americanos: la entrada virreinal en la Nueva España y el Perú”. En Víctor Mínguez Cornelles et alii, La fiesta barroca: los virreinatos americanos (1560-1808). Castelló de la Plana: Universitat Jaume I; Las Palmas: Universidad de las Palmas de Gran Canaria, 2012. (Triunfos Barrocos; 2); pp. 85-104. 


\subsection{México}

ALAMÁN, Lucas. "Entrada de un virey en el reino de Nueva España y toma de posesión del mando". En L. Alamán, Disertaciones sobre la historia de la república megicana, desde la época de la conquista que los españoles bicieron a fines del siglo XIV y principios de XV de las islas y continente americano hasta la independencia. México: Imp. de D. José Mariano de Lara, 1844-1849. 3 v.; vol. III, apéndices, pp. 94-100.

ALBERRO, Solange. "Barroquismo y criollismo en los recibimientos hechos a don Diego López Pacheco Cabrera y Bobadilla, virrey de Nueva España, 1640: un estudio preliminar". Colonial Latin American Historical Review 8:4 (Alburquerque, N.M., 1999): 443-460.

CHIVA BELTRÁN, Juan. "Las entradas triunfales en México: arte, ceremonia y poder durante el siglo XIX”. En La multiculturalidad en las artes y la arquitectura. Actas del XVI Congreso Internacional de Historia del Arte (Las Palmas de Gran Canaria, del 20 al 24 de noviembre de 2006). Las Palmas de Gran Canaria: Gobierno de Canarias; Anroart Ediciones, 2006, vol. II, pp. 297-305.

---- 'El ceremonial de la 'entrada triunfal' en el caso de los últimos virreyes de la Nueva España”. En Inmaculada Rodríguez Moya (ed.), Arte, poder e identidad en Iberoamérica: de los virreinatos a la construcción nacional. Castelló de la Plana: Universitat Jaume I, 2008, pp. 173-203.

---- "Virreyes, dioses y héroes: utilización de la iconografía y los mitos europeos en América". En Juan José Ferrer Maestro y Pedro Barceló (eds.), Europa: historia, imagen y mito. Castelló de la Plana: Universitat Jaume I, 2008, pp. 467-485.

---- "El ocaso de un ceremonial: las últimas entradas virreinales de la Nueva España". En Manuel Chust e Ivana Frasquet (ed.), Actas del XIV Congreso de AHILA Europa-América. Paralelismos en la distancia. Castellón, España, 20-24 septiembre 2005. Madrid: Mapfre, 2008. 1 CD-ROM.

---- "La utilización del género emblemático en las entradas virreinales novohispanas y su proyección en el siglo XIX mexicano”. En Rafael García Mahíques y Vicent Francesc Zuriaga Senent (eds.). Imagen y cultura: la interpretación de las imágenes como Historia cultural. Valencia: Generalitat Valenciana; Universitat Internacional de Gandía, 2008. 2 v. Vol. I, pp. 441-457.

---- El triunfo del virrey. Glorias novohispanas: origen, apogeo y ocaso de la entrada virreinal. Castelló de la Plana: Universitat Jaume I, 2012.

CURIEL, Gustavo. "Fiestas para un virrey: la entrada triunfal a la Ciudad de México del conde de Baños. El caso de un patrocinio oficial, 1660". En Gustavo Curiel 
(ed.), Patrocinio, colección y circulación de las artes. XX Coloquio Internacional de Historia del Arte. México: UNAM, Instituto de Investigaciones Estéticas, 1997, pp. 155-193.

FARRÉ VIDAL, Judith. “Teatro y poder en el México colonial: la entrada del duque de Alburquerque en México (1653)". En Carlos Mata Induráin y Miguel Zugasti (coords.), Actas del Congreso El Siglo de Oro en el nuevo milenio. Navarra: EUNSA, 2005. Vol. I, pp. 671-680.

--- "Espectáculos parateatrales en las entradas de virreyes en la Nueva España: el caso del marqués de Paredes (1680)". Bulletin of the Comediantes 58:1 (Auburn, Alabama, Auburn University, 2006): 73-88.

----- "Cartografía simbólica de la ciudad de México y pedagogía de virreyes (1665-1700)". En Judith Farré Vidal (ed.), Dramaturgia y espectáculo teatral en la época de los Austrias. Madrid: Iberoamericana; Frankfurt am Main, 2009, pp. 167-190 55.

---- "Fiesta y poder en el viaje del virrey marqués de Villena (México, 1640)". Revista de Literatura, vol. LXXIII, no 145 (Madrid, CSIC, enero-junio 2011): 199-218.

FEE, Nancy H. "La entrada angelopolitana: Ritual and Myth in the Viceregal Entry in Puebla de los Angeles". The Americas 52:3 (Washington, 1996): 283-320.

FLINCHPAUGH, Steven. "Economic Aspects of the Viceregal Entrance in Mexico City". The Americas 52:3 (Washington, 1996): 345-365.

GUTIÉRREZ DE MEDINA, Cristóbal. Viaje del virrey marqués de Villena. México: por Juan Ruiz, 1640. Reeditado en México: UNAM, Instituto de Historia, 1947. Introducción y notas de Manuel Romero de Terreros. (Publicaciones del Instituto de Historia. Primera serie; 3).

MORALES FOLGUERA, José Miguel. Cultura simbólica y arte efímero en la Nueva España. Sevilla: Junta de Andalucía, Consejería de Cultura y Medio Ambiente, 1991. Especialmente el capítulo III, "Entrada de virreyes".

---- "Los programas iconográficos en las entradas de virreyes de México". En Actas del VIII Congreso Nacional de Historia del Arte. Mérida: Editora Regional de Extremadura, 1993; vol. II, pp. 745-749.

PANES, Diego. Diario particular del camino que sigue un virrey de México: desde su llegada a Veracruz hasta su entrada pública en la capital. Introducción de Lourdes DíazTrechuelo. Madrid: Centro de Estudios Históricos del Ministerio de Obras Públicas, Transportes y Medio Ambiente, 1994.

\footnotetext{
55 Trata las entradas del marqués de la Laguna (1680) y del conde de Moctezuma (1697).
} 


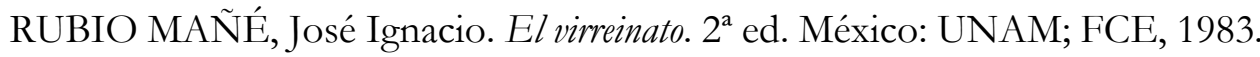
4 v. Especialmente el capítulo IX del vol. I, titulado "Viaje de los virreyes de Nueva España a su destino, llegada y recepción”, pp. 115-197.

\subsection{Perú}

BROMLEY, Juan. "Recibimientos de virreyes en Lima". Revista Histórica XX (Lima, 1953): 5-108.

DURÁN MONTERO, María Antonia. "La entrada en Lima del virrey D. García Hurtado de Mendoza, marqués de Cañete". Laboratorio de Arte 3 (Sevilla, 1990): $57-60$.

JUAN, Jorge y Antonio de ULLOA. Relación histórica del viaje a la América meridional, hecho de orden de S.M., para mediar algunos grados del meridiano. Madrid: por Antonio Marín, 1748. Reeditado facsimilarmente en Madrid: Fundación Universitaria Española, 1978. 2 v. Introducción y edición de José P. Merino Navarro y Miguel M. Rodríguez San Vicente. En la segunda parte, libro I, capítulo IV, se narra la entrada de los virreyes en Lima.

MÁRQUEZ ABANTO, Alberto. "Las comisiones del recibimiento del Excmo. Príncipe de Esquilache”. Revista del Archivo Nacional 14 (Lima, 1941).

MORALES FOLGUERA, José Miguel. "La entrada del arzobispo Morcillo, virrey del Perú, en Potosí (1716) y las sibilas de Puebla". En Jesús María Parrado del Olmo y Fernando Gutiérrez Baños (coords.), Estudios de historia del arte: homenaje al profesor de la Plaza Santiago. Valladolid: Universidad de Valladolid, 2009, pp. 143-148.

MORALES MARTÍNEZ, Alfredo José. "Antes de la fiesta: notas sobre el viaje y recibimiento de los virreyes del Perú". En Francesca Cantú (ed.), Las cortes virreinales de la monarquía española: América e Italia. Roma: Viella, 2008, pp. 465-492.

---- "Etiqueta y ceremonial de los virreyes del Perú: los papeles del marqués del Risco". En Víctor Mínguez (ed.), Las Artes y la arquitectura del poder. Congreso Español de Historia de Arte (19², 2012, Castelló de la Plana). Castelló: Universitat Jaume I, 2013, pp. 407-421.

MORENO CEBRIÁN, Alfredo. "La fastuosa entrada del virrey arzobispo Morcillo en Potosí, 1716”. Torre de los Lujanes 44 (Madrid, mayo 2001): 181-205. 
ORTEMBERG, Pablo. "Teatro, jerarquía y potlatch: examen socio-histórico y antropológico de las entradas virreinales en Lima". Unica: Revista de Artes y Humanidades 16 (Maracaibo, Venezuela, 2006): 13-34.

OSORIO, Alejandra. "La entrada del virrey y el ejercicio del poder en la Lima del siglo XVII". Historia Mexicana, vol. 219, no 55:3 (México, enero-marzo 2006): 767831.

PÉRISSAT, Karine. “Arrivées de vice-rois et événements royaux célebrés au Callao à l'époque coloniale”. Caravelle 69 (Toulouse, 1997): 203-212.

QUEREJAZU ESCOBARI, Lucía. "El programa emblemático alegórico en la entrada del virrey Morcillo a Potosí en 1716". En Memoria del IV Encuentro internacional sobre barroco: la fiesta (La Paz, Bolivia, 2007). Pamplona: Fundación Visión Cultural; Universidad de Navarra, 2011, pp. 149-157. Edición digital a partir de La Paz, Unión Latina, 2007, http://unav.es/publicacion/encuentros-barroco-bolivia/cuarto-encuentro (consultado el 1 de octubre de 2017).

RAMOS SOSA, Rafael. Arte festivo en Lima virreinal, siglos XVI-XVII. Sevilla: Junta de Andalucía, Consejería de Cultura y Medio Ambiente, 1992; especialmente pp. 70-73.

WUFARDEN, Luis Eduardo. "La entrada del virrey arzobispo Morcillo en Potosí". En Los Siglos de Oro en los virreinatos americanos, 1550-1700. Madrid: Sociedad Estatal para la conmemoración de los centenarios de Felipe II y Carlos V, 1999, pp. 146-148.

\subsection{Otros territorios}

VALENZUELA MÁRQUEZ, Jaime. "La recepción pública de una nueva autoridad colonial: modelo peninsular, referente virreinal y reproducción periférica: (Santiago de Chile en el siglo XVII)". En Oscar Mazín Gómez (ed.), México en el mundo hispánico. Zamora, Michoacán: El Colegio de Michoacán, 2000; vol. II, pp. 495-516.

\section{OTRAS CELEBRACIONES EXTRAORDINARIAS}

\subsection{Autos de fe}

\subsubsection{México}

CAÑEQUE, Alejandro. "Writing and Representing the Auto de Fe in Colonial Mexico”. The Americas 52:3 (Washington, 1996): 321-346. 


\subsubsection{Perú}

MONTESINOS, Fernando. Auto de la fe, celebrado en Lima a 23 de enero de 1639. Edición crítica de Marta Ortiz Canseco; coordinación de Esperanza López Parada. Madrid: Iberoamericana, 2016. (Tiempo Emulado. Historia de América y España; 54)

\subsection{Recibimientos del sello real}

\subsubsection{América general}

GÓMEZ GÓMEZ, Margarita. El sello y registro de Indias: imagen y representación. Colonia: Bohlau Verlag, 2008.

---- "La ciudad como emblema: ceremonias de recepción del sello real en Indias". En Manuela Cristina García Bernal y Sandra Olivero Guidobono (coords.), El municipio indiano: relaciones interétnicas, económicas y sociales. Homenaje a Luis Navarro García. Sevilla: Universidad de Sevilla, 2009. (Colección Americana; 41), pp. 461-475.

---- "Imagen y representación del sello real en Indias". En Alejandro Guzmán Brito (editor académico), El Derecho de las Indias Occidentales y su pervivencia en los derechos patrios de América. Actas del decimosexto congreso del Instituto Internacional de Historia del Derecho Indiano celebrado en Santiago de Chile, desde el 29 de septiembre al 2 de octubre de 2008. Valparaíso: Ediciones Universitarias de Valparaíso, 2010; vol. II, pp. 641-656.

\subsubsection{Perú}

ALTUVE-FEBRES, Fernán. "La entrada del sello real en los reinos del Perú". En Alejandro Guzmán Brito (editor académico), El Derecho de las Indias Occidentales y su pervivencia en los derechos patrios de América. Actas del decimosexto Congreso del Instituto Internacional de Historia del Derecho Indiano celebrado en Santiago de Chile, desde el 29 de septiembre al 2 de octubre de 2008. Valparaíso: Ediciones Universitarias de Valparaíso, 2010; vol. II, pp. 657-665.

\subsubsection{Otros territorios}

GARCÍA BERNAL, José Jaime. "El recibimiento del sello real de Carlos IV en la Audiencia de Guatemala (1792): epítome y epígono de una tradición secular". Revista de Humanidades 22 (Sevilla, UNED, mayo-agosto 2014). http://revistas.uned.es/index.php/rdh/issue/view/880 (consultado el 1 de octubre de 2017). (DOI: http://dx.doi.org/10.5944/rdh.22.2014). 
VALENZUELA MÁRQUEZ, Jaime. "Rituales y 'fetiches' políticos en Chile colonial: entre el sello de la Audiencia y el pendón del cabildo". Anuario de Estudios Americanos LVI-2 (Sevilla, julio-diciembre, 1999): 413-440.

\subsection{Victorias militares}

\subsubsection{América general}

GONZÁLEZ CRUZ, David. "Celebraciones de victorias militares de la monarquía hispánica en sus dominios de Europa y América (siglos XVII y XVIII)". En Francisco Núñez Roldán (coord.), Ocio y vida cotidiana en el mundo hispánico en la Edad Moderna. Sevilla: Universidad de Sevilla, 2007. (Historia y Geografía; 120), pp. 231-244.

\subsubsection{México}

GARRIDO ASPERÓ, María José. La fiesta de San Hipólito en la Ciudad de México, 1808-1821. Tesis para obtener el grado de licenciatura. México: UNAM, Facultad de Filosofía y Letras, 1996.

\subsection{Beatificaciones y canonizaciones}

\subsubsection{México.}

SERRANO MARTÍN, Eliseo. “Annus Mirabilis: fiestas en el mundo por la canonización de los jesuitas Ignacio y Francisco Javier en 1662”. En José Luis Betrán (ed.), La Compañia de Jesús y su proyección en el mundo hispánico durante la Edad Moderna. Madrid: Sílex, 2010, pp. 297-34356.

\subsubsection{Perú}

HAMPE MARTÍNEZ, Teodoro, Santidad e identidad criolla: proceso de canonización de Santa Rosa. Cuzco: Centro de Estudios Regionales Andinos Bartolomé de las Casas, 1998.

VARGAS LUGO, Elisa. "Las fiestas de la beatificación de Rosa de Lima". En El arte efimero en el mundo hispánico. México: UNAM, Instituto de Investigaciones Estéticas, 1983. (Estudios de Arte y Estética; 17), pp. 85-105.

\footnotetext{
56 Analiza las celebraciones habidas en Madrid, Lisboa y México.
} 


\subsubsection{Otros territorios}

CAMPOS Y FERNÁNDEZ DE SEVILLA, Francisco Javier. "Barroco efímero y religiosidad popular: fiestas de canonización de Sto. Tomás de Villanueva en Cartagena de Indias". Revista Agustiniana 22 (Madrid, 1992): 1399-1451.

\subsection{Otras fiestas extraordinarias}

BARRUCHI Y ARANA, Joaquín. Relación del festejo que a los marqueses de las Amarillas les hicieron las señoras religiosas del convento de San Jerónimo (México, 1756). Edición de Frederick Luciani. Madrid: Iberoamericana; Frankfurt am Main: Vervuert, 2001. (Biblioteca Indiana; 30).

MEJÍAS ÁLVAREZ, María Jesús. "La muerte del pontífice: las exequias del Papa Clemente XIV en Cartagena de Indias". Ensayos 4 (Bogotá, Universidad Nacional de Colombia, Facultad de Arte, Instituto de Investigaciones Estéticas, 1997): 147-157.

VÁZQUEZ CIENFUEGOS, Sigfrido. "Omnia Vanitas: festejos en honor de Godoy en La Habana en 1807”. En Josef Opatrný (ed.), El Caribe hispano de los siglos XIX y XX: viajeros y testimonios. Praga: Universidad Carolina, 2010. (Ibero-Americana Pragensia-Supplementum; 25/2009), pp. 115-138.

\section{LA FIESTA SACRAMENTAL DEL CORPUS CHRISTI}

\subsection{América general}

MÍNGUEZ, Víctor; Inmaculada RODRÍGUEZ MOYA; Pablo GONZÁLEZ TORNEL y Juan CHIVA BELTRÁN. "El triunfo católico: la fiesta del Corpus Christi". En Víctor Mínguez Cornelles et alii, La fiesta barroca: los virreinatos americanos (1560-1808). Castelló de la Plana: Universitat Jaume I; Las Palmas: Universidad de las Palmas de Gran Canaria, 2012. (Triunfos Barrocos; 2); pp. 123-138.

\subsection{México}

BUELNA SERRANO, María Elvira. "Corpus Christi en México”. En Gerardo Fernández Juárez y Fernando Martínez Gil (coords.), La fiesta del Corpus Christi. Cuenca: Universidad de Castilla-La Mancha, 2002, pp. 285-298.

GRUZINSKI, Serge. "El Corpus Christi en tiempos de la Nueva España”. En Antoinette Molinié (coord.), Celebrando el Cuerpo de Dios. Lima: Pontificia Universidad Católica del Perú, Fondo Editorial, 1999, pp. 151-174. 
PALOMO INFANTE, María Dolores. "La eucaristía en el ámbito maya: las cofradías del Santísimo Sacramento". En Gerardo Fernández Juárez y Fernando Martínez Gil (coords.), La fiesta del Corpus Christi. Cuenca: Universidad de Castilla-La Mancha, 2002, pp. 299-324.

SIGAUT, Nelly. "Corpus Christi: la construcción simbólica de la ciudad de México”. En Víctor Manuel Mínguez Cornelles (coord.), Del libro de emblemas a la ciudad simbólica. Actas del III Simposio Internacional de Emblemática Hispánica. (Benicàssim 1999). Castelló de la Plana: Universitat Jaume I, 2000, vol. I, pp. 27-58.

---- "La fiesta del Corpus Christi y la formación de los sistemas visuales". En Memoria del IV Encuentro internacional sobre barroco: la fiesta (La Paz, Bolivia, 2007). Pamplona: Fundación Visión Cultural; Universidad de Navarra, 2011, pp. 123-134. Edición digital a partir de La Paz, Unión Latina, 2007, http:// unav.es/publicacion/encuentros-barrocobolivia/cuarto-encuentro (consultado el 1 de octubre de 2017).

\subsection{Perú}

BERNALES BALLESTEROS, Jorge. "El Corpus Christi: fiesta barroca en Cuzco". En Primeras jornadas de Andalucía y América (Universidad de Santa María de la Rábida, Huelva, 1981). Huelva: Instituto de Estudios Onubeneses, 1981; tomo II, pp. 275-292. Reeditado, como edición independiente, en Sevilla: Fundación El Monte; Unión Latina; Universidad de La Rábida, 1996. (Colección Literaria).

DEAN, Carolyn S. "Ethnic conflict and Corpus Christi in colonial Cuzco". Colonial Latin American Review II: 1-2 (Alburquerque, N.M., 1993): 93-120.

FERNÁNDEZ JUÁREZ, Gerardo. "Socarte: un Corpus amerindio". En Gerardo Fernández Juárez y Fernando Martínez Gil (coords.), La fiesta del Corpus Christi. Cuenca: Universidad de Castilla-La Mancha, 2002, pp. 363-381.

FLORES OCHOA, Jorge. "Historia, fiestas y encuentro en el Corpus Christi cuzqueño". En La fiesta en el arte. Lima: Banco de Crédito del Perú, 1994, pp. 39-59.

HUAYHUACA VILLASANTE, Luis Alberto. La festividad del Corpus Christi en el Cusco. Cusco: el autor, 1988.

MOLINIÉ, Antoinette. "Hacia una antropología comparativa iberoamericana: dos celebraciones de Corpus Christi, en los Andes y La Mancha". Antropologia: Revista de Pensamiento Antropológico y Estudios Etnográficos 10 (Madrid, octubre de 1995): 41-71. 
---- "Dos celebraciones 'salvajes' del Corpus Christi: (los Andes y La Mancha)". En Antoinette Molinié (coord.), Celebrando el Cuerpo de Dios. Lima: Pontificia Universidad Católica del Perú, Fondo Editorial, 1999, pp. 242-282.

--- "Las dos caras de una custodia: una invención andina de Corpus Christi". En Gerardo Fernández Juárez y Fernando Martínez Gil (coords.), La fiesta del Corpus Christi. Cuenca: Universidad de Castilla-La Mancha, 2002, pp. 347-361.

La PROCESIÓN del Corpus Domini en el Curco. Sevilla: Unión Latina; Universidad de La Rábida, 1996.

URBANO, Henrique. "El Corpus Christi del Cuzco (Perú) o la sociedad cuzqueña como espectáculo”. En Gerardo Fernández Juárez y Fernando Martínez Gil (coords.), La fiesta del Corpus Christi. Cuenca: Universidad de Castilla-La Mancha, 2002, pp. 325-346.

ZUIDEMA, R. Tom. "La fiesta del Inca, el Corpus Christi y la imaginación celestial: castigo y sacrificio humano como ritos de comunión". En Antoinette Molinié (coord.), Celebrando el Cuerpo de Dios. Lima: Pontificia Universidad Católica del Perú, Fondo Editorial, 1999, pp. 191-244.

\subsection{Otros territorios}

DUARTE, Carlos F. "Las fiestas del Corpus Christi en la Caracas hispánica: (tarascas, gigantes y diablitos)". Archivo Español de Arte, tomo 64, nº 255 (Madrid, CSIC, 1991): 337-348.

\section{FIESTAS CORTESANAS EN LAS ISLAS FILIPINAS}

DUEÑAS OLMO, Antonio y Elia GARCÍA OLMO. "Fiestas reales en Manila en el siglo XVIII". En Antonio García-Abásolo (dir.), España y el Pacífico. Actas del congreso internacional Presencia española en el Pacífico (Córdoba, 1995). Córdoba: Asociación Española de Estudios del Pacífico, 1997, pp. 179-184.

HIDALGO NUCHERA, Patricio. "La entrada de los gobernadores en Manila: el ceremonial y sus costes". Revista de Indias, vol. LXXV, no 265 (Madrid, septiembrediciembre 2015): 615-644. (DOI: 10.3989/revindias.2015.019).

---- "El viaje y entrada del gobernador Mariano Ricafort en Manila (1825)". Studia Philologica V alentina 19 (Valencia, 2017): 29-42. 
---- La fidelidad premiada: la entrada del retrato de Fernando VII en Manila el 18 de diciembre de 1825 (en prensa).

MORALES FOLGUERA, José Miguel. "Los túmulos funerarios de Carlos III y la imagen del rey en Hispanoamérica y Filipinas". Boletín de Arte 9 (Málaga, Universidad de Málaga, 1988): 135-158.

MORENO GARBAYO, Justa. Fiestas en Manila, año 1825. Madrid: Patrimonio Nacional, 1977.

\section{DE LAS FIESTAS MONÁRQUICAS A LAS FIESTAS CÍVICAS DE LAS NUEVAS PATRIAS}

\subsection{América general}

ORTEMBERG, Pablo. "Sentidos e historia de las fiestas patrias: una introducción". En Pablo Ortemberg (dir.), El origen de las fiestas patrias: Hispanoamérica en la época de la Independencia. Rosario, Argentina: Prohistoria Ediciones, 2013, pp. 11-25.

ORTEMBERG, Pablo (dir.). El origen de las fiestas patrias: Hispanoamérica en la época de la Independencia. Rosario, Argentina: Prohistoria Ediciones, 2013. (Historia\&Cultura; 10).

\subsection{México}

GARRIDO ASPERÓ, María José. "Las fiestas celebradas en la ciudad de México. De capital de la Nueva España a capital del imperio de Agustín I. Permanencias y cambios en la legislación festiva". En La supervivencia del derecho español en Hispanoamérica durante la época independiente. México: UNAM, Instituto de Investigaciones Jurídicas, 1998, pp. 185-201.

---- "La fiesta de la conquista durante la guerra de la Independencia". Estudios de Historia Moderna y Contemporánea 27 (México, 2004): 5-34.

---- Fiestas cívicas históricas en la ciudad de México, 1765-1823. México: Instituto Mora, 2006. (Historia Política).

PÉREZ MARTÍNEZ, Herón (ed.). México en fiesta. Zamora, Michoacán: El Colegio de Michoacán; Gobierno del Estado, Secretaría de Turismo, 1998.

TORRES BAUTISTA, Mariano. "De la fiesta monárquica a la fiesta cívica: el tránsito del poder en Puebla, 1821-1822". Historia Mexicana, vol. 230, n 45:2 (México, 1995): 221-239. 
ZÁRATE TOSCANO, Verónica. "Fiestas cívicas para la nueva patria en la ciudad de México (1823-1829)". En Pablo Ortemberg (dir.), El origen de las fiestas patrias: Hispanoamérica en la época de la Independencia. Rosario, Argentina: Prohistoria Ediciones, 2013, pp. 237-256.

\subsection{Perú}

ORTEMBERG, Pablo. Rituals du pouvoir à Lima: de la monarchie à la république (1735-1828). París: EHESS, 2012.

---- "Apuntes sobre el lugar de la mujer en el ritual político limeño: de actrices durante el virreinato a actoras de la independencia". E.I.A.L.: Estudios Interdisciplinarios de América Latina y el Caribe 22:1 (Tel Aviv, Israel, 2011): 105-128.

---- "Cádiz en Lima: de las fiestas absolutistas a las fiestas constitucionalistas en la fundación simbólica de una nueva era". Historia 45:2 (Santiago de Chile, juliodiciembre 2012): 455-483.

---- "Soberanía, guerra y calendarios: festejos cívicos en Lima durante la crisis monárquica hasta los años posteriores a Ayacucho (1808-1828)". En Pablo Ortemberg (dir.), El origen de las fiestas patrias: Hispanoamérica en la época de la Independencia. Rosario, Argentina: Prohistoria Ediciones, 2013, pp. 109-130.

\subsection{Otros territorios}

BRIDIKHINA, Eugenia. "La propaganda política y creación del nuevo lenguaje festivo en los primeros años de la república de Bolivia: rupturas y comunidades". Espacio, Tiempo y Forma. Serie V, Historia Contemporánea 22 (Madrid, 2010): 235-265. (DOI: 10.5944/etfv.22.2010).

---- "Cuando se callaron los cañones: conmemoraciones de héroes y batallas en el nacimiento de Bolivia". En Pablo Ortemberg (dir.), El origen de las fiestas patrias: Hispanoamérica en la época de la Independencia. Rosario, Argentina: Prohistoria Ediciones, 2013, pp. 85-107.

CUÑO, Justo. "Ritos y fiestas en la conformación del orden social en Quito en las épocas colonial y republicana (1573-1875)". Revista de Indias, vol. 73, n 259 (Madrid, 2013): 663-692. (DOI: 10.3989/revindias.2013.22). 
DALLA CORTE, Gabriela. "Festividad y contrarrevolución en el Río de la Plata”. En Pilar García Jordán (coord.), Estrategias de poder en América Latina. Barcelona: Universidad de Barcelona, 2000, pp. 165-181.

DÍAZ ARIAS, David. "Las transformaciones de la fiesta en la Costa Rica del ocaso colonial y el alba republicana (1809-1838)". En Pablo Ortemberg (dir.), El origen de las fiestas patrias: Hispanoamérica en la época de la Independencia. Rosario, Argentina: Prohistoria Ediciones, 2013, pp. 187-211.

GARAVAGLIA, Juan Carlos. "A la nación por la fiesta: las fiestas mayas en el origen de la nación en el Plata". Boletín del Instituto de Historia Argentina y Americana "Dr. Emilio Ravignani”, tercera serie, 22 (Buenos Aires, 2000): 73-100.

GONZÁLEZ PÉREZ, Marcos. "La fiesta republicana en Colombia, siglo XIX”. En Marcos González Pérez (autor-comp.), Fiesta y nación en Colombia. Bogotá: Cooperativa Editorial Magisterio, 1998, pp. 51-72.

---- “Fiestas e independencia en Bogotá (1809-1830)”. En Pablo Ortemberg (dir.), El origen de las fiestas patrias: Hispanoamérica en la época de la Independencia. Rosario, Argentina: Prohistoria Ediciones, 2013, pp. 151-169.

MARTÍNEZ, Françoise. "Los usos y desusos de las fiestas cívicas en el proceso boliviano de construcción nacional, siglo XIX". En Marta Irurozqui (coord.), La mirada esquiva: reflexiones politicas sobre la interacción y la ciudadania en los Andes (Bolivia, Ecuadory Perú). Madrid: CSIC; Siglo XXI, 2005, pp. 179-216.

Mc EVOY CARRERAS, Carmen (ed.). Funerales republicanos en América del Sur: tradición, ritual y nación (1832-1896). Santiago de Chile: Centro de Estudios Bicentenario, 2006.

MUNILLA LACASA, María Lía. "Mayo en Buenos Aires: fiestas cívicas y discurso simbólico en el período revolucionario (1810-1816)”. En Pablo Ortemberg (dir.), El origen de las fiestas patrias: Hispanoamérica en la época de la Independencia. Rosario, Argentina: Prohistoria Ediciones, 2013, pp. 43-64.

NÚÑEZ SÁNCHEZ, Jorge. "Las ideas de patria y las fiestas patrias en Ecuador". En Pablo Ortemberg (dir.), El origen de las fiestas patrias: Hispanoamérica en la época de la Independencia. Rosario, Argentina: Prohistoria Ediciones, 2013, pp. 131-149.

PERALTA CABELLO, Paulina Andrea. ;Chile tiene fiesta!: el origen del 18 de septiembre (1810-1837). Santiago de Chile: LOM Ediciones, 2007.

---- "La consagración del 18 de septiembre como fiesta nacional. Trayectoria de la multiplicidad festiva en Santiago de Chile (1810-1837)". En Pablo Ortemberg (dir.), El 
origen de las fiestas patrias: Hispanoamérica en la época de la Independencia. Rosario, Argentina: Prohistoria Ediciones, 2013, pp. 65-83.

PITA PICO, Roger. "La función política de las celebraciones públicas durante el proceso de independencia de Colombia: en la búsqueda de la legitimidad y la lealtad". Historia y Sociedad 23 (Medellín, Colombia, julio-diciembre de 2012): 175-205.

ROJAS, Reinaldo. "El 19 de abril de 1810: primera fecha patriótica venezolana". En Pablo Ortemberg (dir.), El origen de las fiestas patrias: Hispanoamérica en la época de la Independencia. Rosario, Argentina: Prohistoria Ediciones, 2013, pp. 171-185.

SALVADOR, José María. Efimeras efemérides: fiestas cívicas y arte efimero en la Venezuela de los siglos XVII-XIX. Caracas: Universidad Católica Andrés Bello, 2001.

SÁNCHEZ, Susy. "Del Rey monumentalizado a la Patria feminizada: la metamorfosis política en ciudad de Guatemala a través de las celebraciones festivas (17891821)". En Pablo Ortemberg (dir.), El origen de las fiestas patrias: Hispanoamérica en la época de la Independencia. Rosario, Argentina: Prohistoria Ediciones, 2013, pp. 213-235.

ZALDÍVAR, Trinidad. "Fiesta cívica republicana". En Memoria del IV Encuentro internacional sobre barroco: la fiesta (La Paz, Bolivia, 2007). Pamplona: Fundación Visión Cultural; Universidad de Navarra, 2011, pp. 225-234. Edición digital a partir de La Paz, Unión Latina, 2007, http://unav.es/publicacion/encuentros-barroco-bolivia/cuartoencuentro (consultado el 1 de octubre de 2017).

\section{REFERENCIAS BIBLIOGRÁFICAS}

Andrea Sommer-Mathis et alii, El teatro descubre América: fiestas y teatro en la Casa de Austria (1492-1700) (Madrid: Mapfre, 1992).

Angel López Cantos, Juegos, fiestas y diversiones en la América española (Madrid: Mapfre, 1992).

Antonio Lorente Medina, La prosa de Sigüenza y Góngora y la formación de la conciencia criolla mexicana (Madrid: UNED; FCE, 1996).

Antonio Álvarez-Ossorio Alvariño, "La corte: un espacio abierto para la historia social", en La historia social en España: actualidad y perspectivas, coord. Santiago Castillo (Madrid: Siglo XXI, 1991), 247-260. 
Antonio Bonet Correa, "La fiesta barroca como práctica del poder", en El arte efímero en el mundo hispánico (México: UNAM, Instituto de Investigaciones Estéticas, 1983), 43-84.

Bárbara Skinfill Nogal, "Los caminos de la emblemática novohispana: una aproximación bibliográfica”, en Las dimensiones del arte emblemático, eds. Bárbara Skinfill Nogal y Eloy Gómez Bravo (Zamora, Michoacán: El Colegio de Michoacán; Consejo Nacional de Ciencia y Tecnología, 2002), 45-72.

Christian Büschges, "La corte virreinal en la América hispánica durante la época colonial", en Actas del XII congreso internacional de AHIL A, América Latina: outro occidente? Debates do final do milenio, coords. Christian Büschges y Pilar Latasa (Oporto: Centro Leonardo Coimbra de Facultad de Letras, 2001), II, 131-140.

---- "La corte virreinal como espacio político: el gobierno de los virreyes de la América hispánica entre monarquía, élites locales y casa nobiliaria", en El mundo de los virreyes en las monarquías de España y Portugal, eds. Pedro Cardim y Joan-Lluís Palos (Madrid: Iberoamericana; Frankfurt: Vervuert, 2012), 319-343.

Dalmacio Rodríguez Hernández, Texto y fiesta en la literatura novohispana (México: UNAM, Instituto de Investigaciones Bibliográficas, 1998).

Doris Moreno Martínez, "Cirios, trompetas y altares: el auto de fe como fiesta", Espacio, Tiempo y Forma, Serie IV, Historia Moderna 10 (1997): 143-171.

Fernando Checa, "Arquitectura efímera e imagen del poder", en Sor Juana y su mundo: una mirada actual, ed. Sara Poot Herrera (México: Universidad del Claustro de Sor Juana; FCE, 1995), 251-305.

Fernando Montesinos, Auto de la fe, celebrado en Lima a 23 de enero de 1639, ed. Marta Ortiz Canseco (Madrid: Iberoamericana, 2016).

"Fiestas celebradas en Quito cuando la católica majestad de Carlos $3^{\circ}$ pasó del trono de Nápoles al de España, celebradas el año de 1760", Museo Histórico, año V, no 17 (1953): 126-148.

Francisco Cervantes de Salazar, Túmulo imperial de la gran ciudad de México. Descripción que escribió [...] del túmulo que levantó la ciudad de México en las exequias del emperador Carlos V, y de las procesiones y ceremonias que con tal motivo se celebraron [México: 1560; reeditada en la obra México en 1554 y túmulo imperial, ed. Edmundo O’Gorman (México: Porrúa, 1963), 173-212].

Germán Viveros, “Corpus Christi en 1853: añoranza poética mexicana”, en La literatura novohispana: revisión crítica y propuestas metodológicas, eds. José Pascual Buxó y 
Arnulfo Herrera (México: UNAM, Instituto de Investigaciones Bibliográficas, 1994), $145-157$.

Gilbert Ziebura, "Francia en 1790 y 1794: la fiesta como acto revolucionario", en La fiesta: una historia cultural desde la Antigüedad hasta nuestros dias, dir. Uwe Schultz (Madrid: Alianza, 1993), 255-269.

Iván Escamilla González, "La corte de los virreyes", en La ciudad barroca, coord. Antonio Rubial García (México: FCE; Colegio de México, 2005), 371-406.

Jaime Valenzuela Márquez, Las liturgias del poder: celebraciones públicas y estrategias persuasivas en Chile colonial (1609-1709) (Santiago de Chile: Centro de Investigaciones Diego Barros Arana; DIBAM; Lom Editores 2001).

José Manuel Gómez-Tabanera, "Fiestas populares y festejos tradicionales", en El folklore español, ed. J.M. Gómez-Tabanera (Madrid: Instituto Español de Antropología Aplicada, 1968), 149-216.

José Martínez Millán, "La corte de la monarquía hispánica", Studia Historica. Historia Moderna 28 (2006): 17-61.

---- "Introducción. La investigación sobre las élites de poder", en Instituciones y élites de poder en la monarquía hispana durante el siglo XVI, ed. José Martínez Millán (Madrid: Universidad Autónoma de Madrid, 1992), 11-24.

----“Introducción" a La monarquía de Felipe II: la casa del rey, dirs. José Martínez Millán y Santiago Fernández Conti (Madrid: Fundación Mapfre Tavera, 2005), I, 17 51.

José María Díez Borque, "Fiesta popular, cortesana y sacramental en la época de Calderón de la Barca", en El Madrid de Velázquez y Calderón. Villa y corte en el siglo XVII. I. Estudios históricos, eds. Miguel Morán Suriana y Bernardo J. García García (Madrid: Ayuntamiento de Madrid; Fundación Caja Madrid, 2000), 253-276.

Joseph S. Nye, La paradoja del poder norteamericano (Madrid: Taurus, 2003).

Juan de Torquemada, Monarquía indiana (Sevilla: 1615; México: UNAM, Instituto de Investigaciones Históricas, 1975-1983, 7 v.).

Juan Pedro Viqueira Albán, ¿Relajados o reprimidos?: diversiones públicas y vida social en la ciudad de México durante el Siglo de las Luces (México: FCE, 1987).

Karine Périssat, "Las representaciones del espacio americano en las fiestas limeñas de la época colonial”, Criticón 78 (2000): 29-43. 
La fiesta cortesana en la época de los Austrias, coords. María Luisa Lobato y Bernardo J. García García (Valladolid: Junta de Castilla y León, 2003).

La fiesta del Corpus Christi, coords. Gerardo Fernández Juárez y Fernando Martínez Gil (Cuenca: Universidad de Castilla-La Mancha, 2002).

Manuel Rivero Rodríguez, La edad de oro de los virreyes: el virreinato en la monarquía hispánica durante los siglos XVI y XVII (Madrid: Akal, 2011).

M. Gema Palomo Fernández y José Luis Senra Gabriel y Galán, "La ciudad y la fiesta en la historiografía castellana de la Edad Media: escenografía lúdico-festiva", Hispania 186 (Madrid, 1994): 5-36.

María Pilar Monteagudo Robledo, "Fiesta y poder: aportaciones historiográficas al estudio de las ceremonias políticas en su desarrollo histórico", Pedralbes: Revista d'Historia Moderna 15 (1995): 173-204.

Marina Alfonso Mola, "Fiestas en honor de un rey lejano: la proclamación de Felipe V en América", en Felipe V y el Atlántico, ed. Antonio Béthencourt Massieu (Las Palmas de Gran Canaria: Cabildo de Gran Canaria, 2002), 249-308.

Michel Vovelle, Les métamorphoses de la fête en Provence de 1750 à 1820 (París: Aubier-Flammarion, 1976).

---- "De la fiesta tradicional al Estado moderno: la metamorfosis de la fiesta en Francia", en Fiesta y nación en Colombia, autor-comp. Marcos González Pérez (Bogotá: Cooperativa Editorial Magisterio, 1998), 13-26.

Miguel Roiz, "Fiesta, comunicación y significado", en Tiempo de fiesta: ensayos antropológicos sobre las fiestas en España, ed. Honorio M. Velasco (Madrid: Tres-CatorceDiecisiete, 1982), 95-150.

Mona Ozouf, La fête révolutionnaire, 1789-1799 (París: Gallimard, 1976).

Octavio Paz, Sor Juana Inés de la Cruz o las trampas de la fe (Barcelona: Seix Barral, 1982).

Olivier Ihl, La fête républicaine (París: Gallimard, 1996).

Pablo Ortemberg, "Sentidos e historia de las fiestas patrias: una introducción", en El origen de las fiestas patrias: Hispanoamérica en la época de la Independencia, dir. Pablo Ortemberg (Rosario, Argentina: Prohistoria Ediciones, 2013), 11-25.

Pedro Ximena, Reales exequias por el señor D. Carlos III, rey de las Españas y Américas, y real proclamación de su angusto bijo el señor D. Carlos IV por la muy noble y muy leal ciudad de 
Granada, provincia de Nicaragua, reyno de Guatemala [Impreso, 1793; ed. Manuel Ignacio Pérez Alonso (Managua: Banco Central de Nicaragua, 1974)].

Pilar Latasa Vasallo, "La corte virreinal peruana: perspectivas de análisis (siglos XVI y XVII)", en El gobierno de un mundo: virreinatos y audiencias en la América bispánica, coord. Feliciano Barrios (Cuenca: Universidad de Castilla-La Mancha, 2004), 341-373.

Rafael Ramos Sosa, "La fiesta barroca en Ciudad de México y Lima", Historia 30 (1997): 263-286.

Roberto J. López, "Ceremonias y poder en el Antiguo Régimen: algunas reflexiones sobre fuentes y perspectivas de análisis", en Imagen del rey, imagen de los reinos: las ceremonias públicas en la España Moderna, dirs. Agustín González Enciso y Jesús M. Usunáriz Garayoa (Pamplona: EUNSA, 1999), 19-61.

Rodrigo de Carvajal y Robles, Fiestas de Lima por el nacimiento del principe Baltasar Carlos [Lima: 1632; ed. Francisco López Estrada (Sevilla: CSIC, 1950)].

Rosemonde Sanson, Les 14 juillet, 1789-1975, fête et conscience nationale (París: Flammarion, 1976).

Sagrario López Poza, "Los estudios sobre emblemática: logros, perspectivas y tendencias de investigación", SIGNO. Revista de Historia de la Cultura Escrita 6 (1999): 81-95.

Salvador Rodríguez Becerra, "Las fiestas populares: perspectivas socioantropológicas", en Homenaje a Julio Caro Baroja (Madrid: Centro de Investigaciones Sociológicas, 1978), 915-929.

Santiago Martínez Hernández, "Cultura festiva y pode en la monarquía hispánica y su mundo: convergencias historiográficas y perspectivas de análisis”, Studia Historica, Historia Moderna 31 (2009): 127-152.

Víctor Mínguez, "La fiesta política virreinal: propaganda y aculturación en el México del siglo XVII", en La formación de la cultura virreinal. II. El siglo XVII, eds. Karl Kohut y Sonia V. Rose (Madrid: Iberoamericana; Frankfurt, Vervuert: 2004), 359-374.

Recibido: 6 de noviembre de 2017

Aprobado: 15 de enero de 2018 